\title{
Sedimentology and chemostratigraphy of the late Neoproterozoic carbonate ramp sequences of the Hüttenberg Formation (northwestern Namibia) and the C5 Formation (western central Democratic Republic of Congo): Record of the late post-Marinoan marine transgression on the margin of the Congo Craton
} DOI:

10.25131/sajg. 121.0003

\section{Document Version}

Accepted author manuscript

Link to publication record in Manchester Research Explorer

\section{Citation for published version (APA):}

Delpomdor, F., Schröder, S., Préat, A., Lapointe, P., \& Blanpied, C. (2018). Sedimentology and chemostratigraphy of the late Neoproterozoic carbonate ramp sequences of the Hüttenberg Formation (northwestern Namibia) and the C5 Formation (western central Democratic Republic of Congo): Record of the late post-Marinoan marine transgression on the margin of the Congo Craton. South African Journal of Geology.

https://doi.org/10.25131/sajg.121.0003

Published in:

South African Journal of Geology

\section{Citing this paper}

Please note that where the full-text provided on Manchester Research Explorer is the Author Accepted Manuscript or Proof version this may differ from the final Published version. If citing, it is advised that you check and use the publisher's definitive version.

\section{General rights}

Copyright and moral rights for the publications made accessible in the Research Explorer are retained by the authors and/or other copyright owners and it is a condition of accessing publications that users recognise and abide by the legal requirements associated with these rights.

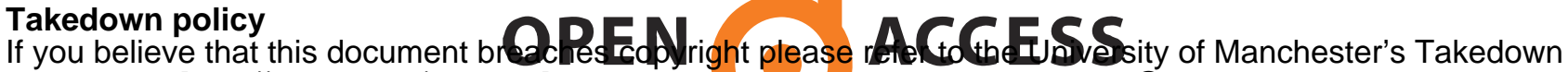
Procedures [http://man.ac.uk/04Y6Bo] or contact uml.scholarlycommunications@manchester.ac.uk providing relevant details, so we can investigate your claim. 
F. Delpomdor, S. Schröder, A. Préat, P. Lapointe, C. Blanpied

1 Sedimentology and chemostratigraphy of the late Neoproterozoic carbonate ramp sequences of the Hüttenberg Formation (northwestern Namibia) and the C5 Formation (western central Democratic Republic of Congo): the Congo Craton

\section{Franck Delpomdor}

Illinois State Geological Survey, University of Illinois, 61820 Champaign, USA.

9 e-mail: fdelpomd@illinois.edu

Stefan Schröder

12 School of Earth and Environmental Sciences, University of Manchester, M139PL,

13 Manchester, United Kingdom

14 e-mail: stefan.schroeder@manchester.ac.uk

\section{Alain Préat}

17 Biogeochemistry and Modelling of the Earth System, Université libre de Bruxelles, 1050

Brussels, Belgium

e-mail:apreat@ulb.ac.be

\section{Philippe Lapointe}

22 GeoCarb Consult, 56 Calle de Narvaez, 28009 Madrid, Spain

23 e-mail: geocarbconsult@att.net 
F. Delpomdor, S. Schröder, A. Préat, P. Lapointe, C. Blanpied

\section{Christian Blanpied}

TOTAL Exploration and Production, Avenue Larribau, 64018 Pau Cedex, France e-mail: christian.blanpied@total.com

Keywords: Ediacaran; Congo Craton; Carbonates; Facies Analysis; Basinal Evolution

\section{Abstract}

The Neoproterozoic Marinoan climatic event corresponded to the SnowballEarth-type glaciation, and is commonly marked by the deposition of diamictites and by a negative carbon isotope anomaly. This event was followed by a sudden return to a greenhouse climate and a rapid post-glacial transgression with deposition of cap carbonates. Although the cap carbonates and marine carbonate sediments at the base of the post-glacial period are well known in the literature, few studies focused on the end of the marine transgression, which is a prelude to the Pan-African Orogenyin Central Africa. In this paper, we present new descriptions of these carbonate rocks and a sedimentological study from key cores and outcrops in the Otavi Mountainland (Namibia) and West Congo belt (DRC) of the Hüttenberg Formation and the C5 Formation, respectively. Both successions show five main facies: (i) microbial 'mounds' and pinnacles, (ii) ooid-shoal barrier, (iii) evaporitic brackish lagoon, (iv) beach and (v) coastal sabkha. The Hüttenberg Formation consists of an open-marine midinner carbonate ramp setting including microbial mounds and pinnacles, and oolitic shoalbarrier islands. The C5 Formation exhibits a hypersaline inner carbonate ramp including an ooid- shoal barrier, an evaporitic brackish lagoon, a beach and a coastal sabkha plain. Sedimentological, chemostratigraphical and biostratigraphical comparisons between the C5 and Hüttenberg formations suggest these are coeval carbonate shelf deposits on the margins 
F. Delpomdor, S. Schröder, A. Préat, P. Lapointe, C. Blanpied

of the Congo Craton, with a depositional age between $580 \mathrm{Ma}$ and $540 \mathrm{Ma}$ for both formations.

\section{Introduction}

The Ediacaran Hüttenberg Formation, the youngest stratigraphic unit in the Otavi Group of the Damara Supergroup in northwest Namibia, comprises a 900 m-thick succession of shales, dolomitic limestones, oolitic limestones, and cherty dolostones. These were deposited in shallow marine environments on the southern and northern passive margins of the Congo-São Francisco (hereafter, C-SF) and Kalahari cratons respectively (Kamona and Günzel, 2007; Figure 1). The sedimentary succession of the C5 Formation of the Cataractes Group (former West Congolian Group), similar to that developed in the Otavi Platform, is also present along the western flank of the Congo Craton in the Democratic Republic of Congo (DRC) (Delpomdor et al., 2018). Both successions record the end of the marine transgression, following Snowball Earth-type Marinoan glaciation (Kirschvink, 1992; Hoffman, 1999; Hoffman et al., 1998; Kennedy et al., 2001; Hoffman and Schrag, 2002). They predate the shutdown of the carbonate factory before the deposition of molasse sequences of the Mulden Group in Namibia and the Mpioka Subgroup in DRC. No datable intrusive or volcanic rocks and biostratigraphic fossils have so far been directly reported from these stratigraphic units and the age of sedimentation of the sedimentary succession in this part of the Ediacaran sedimentary cover of the C-SF and Kalahari cratons remains largely unconstrained.

Nevertheless, the Hüttenberg and C5 formations were constrained by carbon isotopes, which reveal an upwards-increasing trend suggesting a depositional age between 635 and $580 \mathrm{Ma}$ (Halverson et al., 2005; Frimmel et al., 2006). Recent chemostratigraphic and biostratigraphic re-interpretation of the C5 Formation attributed a maximum depositional age of $540 \mathrm{Ma}$ 
F. Delpomdor, S. Schröder, A. Préat, P. Lapointe, C. Blanpied

(Delpomdor et al., 2018). However, a previous study focusing on the temporal carbon isotope trend of Hüttenberg Formation carbonates has considered this to be a Sturtian to Marinoan interglacial interval (Kaufman et al., 2010).

The principal objective of this paper is to contribute to the debate on the age of the Hüttenberg Formation. We present the results of a detailed study on two key sections in the Hüttenberg Formation and the C5 Formation which record the ultimate postglacial marine transgression, before the terminal Neoproterozoic Pan-African orogeny. Here, we describe the depositional characteristics of these two carbonate ramps with a focus on the litho- and microfacies, geometry, and stratigraphic architecture. Based on the new inferred depositional environments of the stratigraphic-equivalent C5 Formation in the DRC, an age for the Hüttenberg and C5 formations can be estimated.

\section{Geological setting and stratigraphy}

\section{Regional geological setting}

\section{9}

Widespread shearing and tectonic escape, post-tectonic magmatism, extension, rifting, and intracontinental mobile belt formation were common on the margin of the C-SF cratons in the period 1000-720 Ma (Stanistreet et al., 1991; Tack et al., 2001; Kamona and Günzel, 2007). These tectonic events postdated the assembly of Rodinia and predated the breakup of this supercontinent. Rifting of the Rodinia supercontinent occurred successively as a series of eastward younging rift basins formed between 1100 and $950 \mathrm{Ma}$ (Unrug, 1995) (Figure 1A).

Separation of the C-SF cratons from Rodinia supercontinent started with the opening of Araçuaí Basin between the C-SF cratons at ca. 1000 Ma (Pedrosa-Soares et al., 2001), and between $999 \pm 7 \mathrm{Ma}$ and $912 \pm 7$ Ma along the western margin of the Congo Craton with the deposition of volcano-sedimentary units and intrusion of peralkaline granitoids of the Matadi 
F. Delpomdor, S. Schröder, A. Préat, P. Lapointe, C. Blanpied

100 and Tshela/Seke Banza groups (Tack et al., 2001; Baudet et al., 2014) (Figure 1B). Rifting

101 and opening of the Adamastor Ocean, between the Kalahari, C-SF and Rio de la Plata cratons, 102 was initiated between 900-760 Ma and was marked by voluminous volcanic effusions and

103 intrusions (Hoffman et al., 1996; McGhee et al., 2012; Miller, 2013). Rifting occurred as

104 transtensional and transpressive events between the Kalahari and C-SF cratons, extended into

105 the Zambezi rift basin, which opened the Khomas-Mozambique Oceans with the deposition of

106 fluvial clastics, intrusion of granitoids and outpouring of lava flows at $880 \mathrm{Ma}$ (Martin, 1965;

107 Hedberg, 1979; Porada and Berhorst, 2000; Armstrong et al., 2005; Li et al.,2008). Rifting

108 spread westwards into the Zambezi and Damara rift basins, and thereafter northwestwards

109 into the area of the Katanga rift Basin (Porada and Berhorst, 2000).

110 Between $920 \mathrm{Ma}$ and $\sim 600 \mathrm{Ma}$, a series of passive margins with deposition of fluvio- to

111 marine siliciclastic and carbonate sediments developed along the margins of the C-SF cratons.

112 The Amazonian-West African-Rio de la Plata cratons (East Gondwana) collided with West

113 Gondwana, creating the Pan-African-Brasiliano orogenic belts on the margin of the C-SF

114 cratons between $\sim 650 \mathrm{Ma}$ and $\sim 515 \mathrm{Ma}$ (Alkmim et al., 2006; Pedrosa-Soares and Alkmin,

115 2011) (Figures 1D, E). West Gondwana was amalgamated with Amazonia, West Africa and

116 C-SF plates at about 200 Ma (Brito-Neves et al., 1999; Cordani et al., 2003) initiating the

117 earlier Pan-African-Brasíliano tectonic episode of the Araçuaí-West Congo Belt (e.g.,

118 Alkmim et al., 2006; Pedrosa-Soares and Alkmin, 2011) (Figure 1E). With the final

119 amalgamation of India to Australia-East Antarctica (e.g., Meert, 2003; Collins and

120 Pisareysky, 2005), the Pan-African orogeny ended. The polyphase assembly of the Gondwana

121 supercontinent during the East Africa, Brasiliano, Kuungan and Damaran orogenic events

122 thus extended from about $1000 \mathrm{Ma}$ to at least the end of the Cambrian ( $540 \mathrm{Ma}$ to $490 \mathrm{Ma}$;

123 Porada, 1989; Stanistreet et al., 1991; Meert, 2003; Begg et al., 2009; Nascimento et al.,

124 2016). 
F. Delpomdor, S. Schröder, A. Préat, P. Lapointe, C. Blanpied

Neoproterozoic stratigraphy in Namibia and DRC

The West Congo Supergroup rests unconformably on the $\sim 2.1$ Ga polymetamorphic Kimezian

basement. It consists of up to $10 \mathrm{~km}$ thick siliciclastic and carbonate sequences with

decreasing regional metamorphism from amphibolite facies in the west, through to unmetamorphosed rocks in the east (Frimmel et al., 2006). The metamorphosed rocks formed in the aulacogen thrust-and-fold belt, whereas the unmetamorphosed units represent deposition in the foreland basin. In Namibia, the Damara Supergroup is up to $14 \mathrm{~km}$ thick and consists of greenschist facies siliciclastics and carbonates deposited on a polymetamorphic Palaeoproterozoic basement.

The Neoproterozoic sedimentary successions in the West Congo and Damara belts are remarkably similar (Figure 2). Both record a long-1iyed initial rift - between $\sim 900-750 \mathrm{Ma}$ for the West Congo Supergroup (Tack et al., 2001; Frimmel et al., 2006), and between 770-750 Ma for the Damara Supergroup (McGhee et al., 2012; Miller, 2013), followed by a passive margin including carbonate platform deposits, and final continental collision between the Rio

141 de la Plata and C-SF cratons approximately between 600 to $550 \mathrm{Ma}$ (Merdith et al., 2017).

142 Rift deposition is generally recorded by continental and rift-related volcano-sedimentary

143 rocks. These are overlain by fluvio-deltaic siliciclastic and marine carbonates deposited on a

144 passive margin. Continental collision and foreland basin deposition are recorded in the red 145 bed facies of the 580-535 Ma Mulden Group in Namibia (Clauer and Kröner, 1979; Hedberg, 146 1979; Miller, 2008; Germs et al., 2009) and in the 566-490 Ma Mpioka Subgroup in DRC and 147 Angola (Frimmel et al., 2006; Monié et al., 2012) (Figure 2).

148 In the West Congo Supergroup, up to two diamictite units, the Lower Diamictite Formation 149 and the Upper Diamictite Formation (Lepersonne, 1951) have been interpreted, respectively, 
F. Delpomdor, S. Schröder, A. Préat, P. Lapointe, C. Blanpied

150

151

152

153

154

155

156

157

158

159

160

161

162

163

164

165

166

167

168

169

170

171

172

173

174

as Sturtian (U-Pb age on baddeleyite single-grains: $694 \pm 4 \mathrm{Ma}$; Straathof, 2011) and

Marinoan in age (Frimmel et al., 2006; Tait et al., 2011). In Namibia, glacial diamictites and associated cap carbonates occur at the base of the Abenab (Sturtian) and Tsumeb (Marinoan) subgroups, the Varianto and Ghaub formations respectively (Figure 2). The maximum age of the Varianto Formation is $746 \pm 2$ Ma based on $\mathrm{U}-\mathrm{Pb}$ ages in a tuff of the Naauport Formation west of the Otavi Montainland (Hoffman et al., 1994; Hoffmann and Prave, 1996.). A coevval depositional age of $760 \pm 1$ Ma was obtained from zircon grains (U-Pb TIMS) in a tuff of the Devede Formation (Ombombo Subgroup) in the Summas Mountains (Halverson et al., 2005). The Marinoan-equivalent Ghaub Formation yielded U-Pb zircon ages between $639.3 \pm 0.3$ Ma and $635 \pm 1.2 \mathrm{Ma}$, based on zircon grains of an ash layer in the Ghaub Formation in northwestern and south-central Namibia respectively (Hoffmany et al., 2004; Prave et al., 2016). An age of $635.2 \pm 0.6 \mathrm{Ma}$ obtained from an ash bed in the basinal equivalent of the

Ghaub Formation in south-central Namibia constrains the top of the Ghaub Formation (Prave et al., 2016).

Our study will focus on the open-marine to lagoonal carbonates of the Hüttenberg Formation (Tsumeb Subgroup) and the stromatolitic and oolitic C5 Formation of the Lukala Subgroup in Namibia and DRC, respectively. The Hüttenberg Formation is constrained by the stratigraphically-equivalent Kuiseb Formation in south-central Namibia, which yielded U-Pb detrital zircon ages between $606 \pm 24 \mathrm{Ma}$ and $587 \pm 9 \mathrm{Ma}$ (Foster et al., 2015). ${ }^{40} \mathrm{Ar}-{ }^{39} \mathrm{Ar}$ metamorphic ages of 590 Ma were obtained in the Kuiseb Formation in the Austerlitz area (Lehmann et al., 2016). The C5 Formation is constrained between $\sim 575 \mathrm{Ma}$ and $566 \pm 42$ Ma, based on ${ }^{87} \mathrm{Sr} /{ }^{86} \mathrm{Sr}$ ratios in carbonate rocks of the underlying C4 Formation (Poidevin, 2007) and ${ }^{40} \mathrm{Ar}-{ }^{39} \mathrm{Ar}$ metamorphic ages obtained in the Mpioka Subgroup (Frimmel et al., 2006) respectively. Recently, the age of the C5 Formation was refined between 575 and 540 Ma based on new chemostratigraphic and biostratigraphic data (Delpomdor et al., 2018). 
F. Delpomdor, S. Schröder, A. Préat, P. Lapointe, C. Blanpied

\section{Methods}

177

178 This study is based on detailed facies descriptions and petrographic analyses of the

179 Hüttenberg and C5 formations (Figure 3A). Six cores and two outcrop sections around the

180 towns of Tsumeb and Abenab (Namibia) (Figure 3B) and two cores from Bamba Kilenda

181 village (Figure 3C), located $150 \mathrm{~km}$ southwest of Kinshasa (DRC) are described in detail.

182 Outcrop sections are located in the Tsumeb mine and west of Tsumeb along the B1 Road

183 (Figures 3C and 4). Cores were sampled at the Tsumeb Mine (core S\#66), Yogelsang 284

184 Farm (core MJNM\#5-10), Guinab Farm (core MJNM\#6-9), and Bombay Farm (core

185 MJNM\#12) located to the northwest of Abenab (Figures 3C and 5). In addition, two cores

186 (Gx6c and GN7/9a) from the northern side of the Bamba Kilenda anticline were sampled at

187 the Royal Museum for Central Africa, Belgium (Figures 3B and 6). A total of 406 samples

188 encompassing the T7 and T8 Hüttenberg Formation in Namibia, and the C5 Lukala Formation

189 in DRC were collected at intervals of approximately $\sim 5 \mathrm{~m}$ and $\sim 50 \mathrm{~cm}$ respectively. Drawings

190 from photographic sketches are used to detail the geometry and internal sedimentary

191 structures of beds.

192 Forty-eight samples were selected for whole rock carbon isotopic analyses. Carbonate

193 powders were reacted with $100 \%$ phosphoric acid (density $>1.9$, Wachter and Hayes, 1985) at

$19475^{\circ} \mathrm{C}$ using a Kiel III online carbonate preparation line connected to a ThermoFinnigan 252

195 mass spectrometer. All values are reported in per mil relative to V-PDB by assigning a $\delta^{13} \mathrm{C}$

196 value of $+1.95 \%$ o to NBS19. The reproducibility of $\delta^{13} \mathrm{CV}$-PDB measurements is $0.04 \%$

$197(1 \sigma)$. 
F. Delpomdor, S. Schröder, A. Préat, P. Lapointe, C. Blanpied

198 Three samples were selected for $\mathrm{Sr}$ isotopes analyses. Sr values were measured using a VG54

199 multicollector mass spectrometer at the Université libre de Bruxelles (Belgium). The ${ }^{87} \mathrm{Sr} /{ }^{86} \mathrm{Sr}$

200 values were normalized to ${ }^{86} \mathrm{Sr} /{ }^{88} \mathrm{Sr}=0.1194$.

201

202 Stratigraphic framework of the studied successions

203 Hüttenberg Formation, Namibia

204

205 The thickness of the Hüttenberg Formation is approximately $900 \mathrm{~m}$ (Porada, 983). The lower 206 part of the Hüttenberg Formation consists of up to $15 \mathrm{~m}$-thick, light to dark grey-blue

207 coloured, finely bedded shaley and laminar dolostone with Conophyton-type stromatolite, 208 dolarenite, cherts and local breccia (Figure 4A).

209 The middle part of the Hüttenberg Formation contains, from base to top, (1) yellow to brown

210 dolomitic shale with dark chert, (2) dark blue-grey laminar limestone, locally dolomitic, (3)

211 yellow to brown dolomitic shales overlain by dark grey dolostone with breccia and brown

212 shale interbeds, and (4) light blue-grey dolostone with white bluish nodules of anhydrite

213 (Figure 4B). The uppermost part of this unit contains shallowing-upward sequences of dark

214 grey dolostone, passing to grey planar to wavy laminar dolostone, overlain by blue-grey

215 oolitic dolostone, often silicified, with planar and crossed laminations. Beds of blue-grey

216 medium- to cóarse-grained dolarenites and interbeds of dark cherts are also present.

217 The upper part of the Hüttenberg Formation is up to $250 \mathrm{~m}$-thick and dominated by pale to

218 dark blue-grey bedded laminar dolomitic limestone and dolostone interbedded with red to

219 yellow dolomitic shale, blue-grey impure shaley limestone, and blue-grey oolitic limestone.

220 Breccia and blue-grey calcarenite are also common (Figure 4C). Up to $9 \mathrm{~m}$-thick evaporite

221 beds with nodules of anhydrite and gypsum are locally observed (Kamona and Günzel, 2007). 
F. Delpomdor, S. Schröder, A. Préat, P. Lapointe, C. Blanpied

222 The top of the Hüttenberg Formation consists of up to $200 \mathrm{~m}$-thick pale greenish/brownish to

223 dark grey massive to laminar dolomitic limestone with interbeds of reddish to greenish-yellow

224 dolomitic shale, locally dark-grey silicified oolitic limestone, passing to pale brownish to dark

225 grey fine- to medium-grained dolostone interlayered by reddish brown dolomitic shale

226 (Figures 5A-E). Horizons and nodules of dark chert and white talc are also common. Massive

227 dolerite $0.70 \mathrm{~m}$ in thickness locally intrudes this unit (Figure 5D).

C5 Formation, Lukala Subgroup, DRC

The C5 Formation (estimated thickness between $150 \mathrm{~m}$ and $300 \mathrm{~m}$; Lepersonne, 1973) is divided, from the oldest to youngest, into C5a, C5b and upper C5b members. The C5a member consists of 20-40 m-thick light grey lime conglomerate and breccia, light- to darkcolored oolitic limestone and dolomitized limestone) with cyanobacterial mats, evaporitic (anhydrite after gypsum) and chert horizons.

The C5b Member is an approximately $40 \mathrm{~m}$-thick dominant dark greenish to dark grey massive to laminar limestone, often dolomitic. It locally contains small-scale LLH-type

238 stromatolites, and $\mathrm{cm}$ - to dm-thick well sorted dark grey to dark oolitic limestone including

239 Obruchevella parva in the nucleus, e.g., the "Kisantu Oolite", which is locally silicified

240 (Figures 6A-B). Low-angle cross-laminations, rare ripples, erosional gutter casts and

241 desiccation cracks are present. Dark grey lime mudstone with whitish nodules of calcite

242 pseudomorphs of anhydrite and gypsum, yellow to reddish brown hardgrounds and

243 desiccation crack surfaces are associated. Filamentous cyanobacterium Obruchevella parva 244 was identified in the "Kisantu Oolite" in the stratigraphic-equivalent SCIII Formation in the 245 Republic of Congo (RC) (see Alvarez et al., 1995). 
F. Delpomdor, S. Schröder, A. Préat, P. Lapointe, C. Blanpied

246 The overlying upper C5b Member is subdivided into C5b1 and C5b2 submembers

247 (Lepersonne, 1973). The C5b1 submember, locally 95-135 m-thick, consists of approximately

$24840 \mathrm{~m}$ of light to dark greyish laminar to nodular dolomitic limestone, locally dolostone, with

249 frequent ripples, yellow to reddish brown hardgrounds, desiccation cracks and calcretes. It is

250 interbedded with reddish to dark grey dolomitic shale, and dark grey lime mudstone (Figure

251 6B). Nodules of calcite pseudomorphs of anhydrite and gypsum are common in this

252 submember.

253 The C5b2 submember comprises 30-50 m-thick light greyish to whitish dolomitic limestone

254 including cm-thick beds of silicified oolites, locally with talc. In the study area, it was eroded

255 by the overlying Mpioka Subgroup and was not investigated in detail.

\section{Lithofacies and microfacies associations}

Twelve microfacies (MF1 to MF12) are recognized from outcrop and core sections and thin-

section examination in the T7-T8 Hüttenberg and C5 formations. Lithology, sedimentary

structures and textures, and fossil contents allow a grouping into nine lithofacies associations,

262 LFA-H1 to LFA-H4 and LFA-C1 to LFA-C5 for the Hüttenberg and C5 formations

263 respectively. Lithofacies associations and microfacies are summarized in Table 1, and shown

in Figures 4-6.

Hüttenberg Formation (Namibia)

\section{Lithofacies association H1 (LFA-H1)}

Lithofacies association $\mathrm{H} 1$ only includes argillaceous (dolo)mudstone (MF1). In outcrop and 
F. Delpomdor, S. Schröder, A. Préat, P. Lapointe, C. Blanpied

271 argillaceous seams and stylolites. With increasing degree of dolomitization, the lithofacies

272 may grade into medium to coarse grained dolomitic calcarenite and dolarenite. The massive

273 micritic matrix (4-15 $\mu \mathrm{m}$ in size) is recrystallized to neomorphic microspar (15-20 $\mu \mathrm{m}$ in size)

274 (Plate 1A). The dolomitic microfacies is composed of medium to coarse crystalline euhedral

275 to anhedral dolomitic rhombs $(50-100 \mu \mathrm{m}$ in size $)$ with rare intercrystalline clay seams. Silt-

276 to sand-sized grains of quartz $(>10 \% \mathrm{wt}$.$) , feldspars ( >5 \% \mathrm{wt}$.$) and micas (>20 \% \mathrm{wt}$.$) are$

277 observed. No sedimentary structures were observed in this microfacies.

278 LFA-H1 is interpreted as low-energy lime muds deposited in a subtidal open-marine

279 environment with detrital contributions. The absence of evaporites excludes protected

280 conditions like lagoons. An open lagoon connected to the open sea via tidal inlets and with

281 normal salinity is unlikely due to the low variety of sediment types and the absence of distinct

282 tidal features.

Lithofacies association H2 (LFA-H2)

Lithofacies association 2 contains laminated (dolo)mudstone (MF2) and calcimicrobial

287 (dolo)bindstone (MF3). The former consists of millimeter-scale laterally continuous light to

288 dark brown, planar to yispy parallel, thin- to non-laminated mudstone. The matrix of the thin-

289 to non-laminated mudstone is composed of fine micrite $(5-10 \mu \mathrm{m}$ in size) (Plate $1 \mathrm{~B})$, replaced

290 by a neomorphic microspar $(15-30 \mu \mathrm{m}$ in size $)$. Dolomitization is fairly common. The contact

291 between the laminations is gradual.

292 Calcimicrobial bindstone (MF3) consists of submillimetric-scale, irregular and continuous,

293 thin planar to wavy parallel microbial tubular filaments in a dark brown micrite matrix.

294 Locally, the microfacies shows a closely-packed texture of randomly oriented tubular

295 filaments and clumps of cyanobacteria micro-organisms. The filaments are dominantly non- 
F. Delpomdor, S. Schröder, A. Préat, P. Lapointe, C. Blanpied

296

297

298

299

300

301

302

303

304

305

306

307

308

309

310

311

312

313

314

315

316

317

318

319

320

branched, non-septate, discrete tubules with a diameter between $50 \mu \mathrm{m}$ and $500 \mu \mathrm{m}$ (Plate

1C). Tubules with a diameter between $5 \mu \mathrm{m}$ and $20 \mu \mathrm{m}$ display dark-colored micritic walls (4$8 \mu \mathrm{m}$ of thickness) often filled with equant sparry crystals (10-20 $\mu \mathrm{m}$ in size). Clumps are irregular and elongate, and form ellipsoid patches rimmed by a diffuse dark-colored micrite.

Clumps rarely contain discrete remnants of tubular filaments.

With increasing degree of dolomitization, the matrix shows fine crystalline euhedral to anhedral dolomitic rhombs (4-20 $\mu \mathrm{m}$ in size) in equigranular mosaic fabrics. Swallowtail twins, platy rectangular laths and nodules filled by calcite, replacing gypsum and anhydrite, are fairly common in these both microfacies. Silt- to sand-sized grains of quartz ( $>5 \% \mathrm{wt}$.), feldspars ( $>5 \%$ wt.) and micas ( $>2 \%$ wt.) were observed.

Microfacies 2 and 3 are interpreted to have accumulated in low to moderate energy environments in the photic zone, which facilitated the seasonal carbonate production by cyanobacteria (Gerdes et al., 1994). Locally, the Cyanobacteria formed small-scale calcimicrobial biostromes that are common on a carbonate mid-ramp setting (Turner et al., 2000).

\section{Lithofacies association H3 (LFA-H3)}

Two microfacies, peloidal (dolo)wackestone-(dolo)packstone (MF4) and stromatolitic (dolo)boundstone (MF5) form lithofacies association 3. In outcrop and core sections, MF4 only occurs in the T8 unit of the Hüttenberg Formation. Stromatolites of LLH-type, and locally spheroidal structures, Conophyton stromatolites are identified in this lithofacies. In thin section, MF4 consists of silt- to sand-sized irregular micritic peloids, locally cemented by radiaxial spar (Plate 1D), in a fine microcrystalline micritic matrix. The microfacies is characterized by abundant irregular pseudo-fenestrae, filled by an equant calcite cements. 
F. Delpomdor, S. Schröder, A. Préat, P. Lapointe, C. Blanpied

321 MF5 displays thin sub-millimetric-scale, irregular, horizons of stromatolitic mats and clumps

322 of cyanobacterial micro-organisms in a micritic to microsparitic matrix. Stromatolitic mats are

323 planar to wavy and consist of dark micritic laminae up to $50 \mu \mathrm{m}$ in thickness. The grumeaux

324 consist of irregular and dark micritic rounded patches of stromatolites up $300 \mu \mathrm{m}$ in size

325 (Plate 1E), often filled by equant calcite cements (up to $50 \mu \mathrm{m}$ in size). This microfacies

326 locally shows vugs, veins, and desiccation cracks filled by bladed calcite cements associated

327 with botryoidal and radiaxial cements. Both microfacies contain silt-to-sand-sized grains of

328 quartz (10 to $50 \mu \mathrm{m}$ of size, $>2 \%$ wt.), fine-grained pyrites (less than $10 \mu \mathrm{m}$ of diameter, $>5 \%$

329 wt.) and remnant of tubular filaments are observed. The lithofacies association 3 is variably

330 dolomitized, forming dolomudstone and dolorenite, with original textures obscured in outcrop

331 and core sections, but commonly visible in thin sections

332 The lithofacies association 3 corresponds to stromatolitic pinnacles in low- to moderate-

333 energy conditions. Similar lithofacies have been described in the Neoproterozoic sedimentary

334 successions from Canada (Batten et al., 2004: Thomson et al., 2014). Peloids formed the base

335 of the stromatolitic buildups through the encrustations of micrite (probable aragonite mud)

336 around cyanobacteria or as decomposition products of various algae (Flügel, 2010). The

337 occurrence of pseudo-fenestrae associated with subspherical fenestrae suggests a shallow

338 near-coastal peritida environment (Flügel, 2010). Botryoidal cements are usually marine, and

339 are common) in cavities of reefs and in steep seaward dipping slopes (James and Ginsburg

$340 \quad 1979)$.

341

342 Lithofacies association H4 (LFA-H4)

344 Lithofacies association 4 only includes oolitic (dolo)packstone-(dolo)grainstone (MF6). The

345 microfacies dispays light blue-grey, medium- to well-sorted calcarenites and dolarenites with 
F. Delpomdor, S. Schröder, A. Préat, P. Lapointe, C. Blanpied

346 indistinct cross laminations. In thin sections, MF6 consists of 1-2 mm-thick layers of

347 medium- to well-sorted (dolomitized) oolitic packstone-grainstone (Plates 1F-H). The oolites

348 occur either in a tightly packed dark brown lime matrix (packstone) or in coarse-crystalline

349 lighter-coloured drusy sparry cements (grainstone). Sedimentary structures include wedge-

350 shaped planar or trough cross laminations. The oolites are predominantly spherical to ovoid

351 with a dark microcrystalline micritic fabric in the cortex. Alternatively, they consist of

352 concentric tangential grains, or are grouped in coarse-grained grapestones (up to $1 \mathrm{~mm}$ )

353 These latter are moderately elongated, flattened and stretched. Silicified yellow-colored

354 oolites are locally observed. Associated with oolites, coalescent flattened peloids, debris of

355 probable cyanobacterial mats (microbial chips) and vertical desiccation cracks are also

356 observed.

357 In the Hüttenberg Formation, oolites represent a beach-barrier island environment. Trough

358 cross-laminations indicate deposition in high-energy environments such as sandy carbonate

359 shoals. Concentric oolites are common of high-energy in shorefaces and shoals (Burchette

360 and Wright, 1992). Oolites and microbial chips result from reworking of fore- to back-barrier

361 sediments (e.g., muds, cyanobacterial mats) by fair-weather waves, storms and/or tides.

363 C5 Formation (DRC)

364 Lithofacies association C1 (LFA-C1)

366 This lithofacies association includes argillaceous mudstone (MF7) and laminated mudstone

367 (MF8). Argillaceous mudstones (MF7) consist of dark-grey, locally pale pinkish, massive

368 limestone with thin argillaceous seams and stylolites. In thin section, the microfacies is

369 characterized by a fine micritic matrix (Plates 1H-I), locally neomorphosed to microspar (15-

$37020 \mu \mathrm{m}$ in size). Where dolomitized, the matrix displays fine-grained hypidio- to xenotopic 
F. Delpomdor, S. Schröder, A. Préat, P. Lapointe, C. Blanpied

371 dolomitic rhombs $(5-10 \mu \mathrm{m}$ in size $)$. Wispy microbial mats, microbial chips, and isolated

372 peloids, are also present observed. Mudstones (MF8) consist of laterally continuous dark 373 grey, planar to wavy parallel, thin laminated limestone. Oblique and cross-laminations are

374 also present. The laminations display dark brown micrite (up to $10 \mu \mathrm{m}$ in size), locally with

375 peloidal fabric (Plates $1 \mathrm{I}-\mathrm{J})$. The matrix is partially neomorphosed to microspar $(15-30 \mu \mathrm{m}$ in

376 size) or, replaced by idio- to hypidiotopic dolomicrosparitic crystals (up to $50 \mu \mathrm{m}$ in size).

377 This lithofacies association contains silt-sized quartz, irregular and flattened peloids (up to 20

$378 \mu \mathrm{m}$ of diameter), randomly oriented swallowtail twins and platy rectangular laths of replaced

379 gypsum, stratabound nodules and enterolithic anhydrite replaced by calcite cements.

380 The argillaceous mudstone (MF7) is interpreted as low-energy lime muds deposited in

381 subtidal environments. The occurrence of anhydrite pseudomorphs points to protected

382 lagoonal conditions, probably barred by sandy shoals and reefs. The association with the

383 laminated mudstone (MF8) is also inferred to lowenergy inter- to supratidal lagoonal settings

384 colonized by cyanobacterial mats periodically reworked by intertidal currents. Arid conditions

385 are recorded by the precipitation of stratabound gypsum and anhydrite.

387 Lithofacies association C2 (LFA-C2)

389 Lithofacies asssociation C2 is abundant in the C5b Member of the C5 Formation and consists

390 of dark coarse grained, well-sorted, crossed laminated oolitic grainstone (MF9). Grainstone

391 contains tighly-packed spheroidal to ellipsoidal siliceous ooids and pisoids up to $50 \mu \mathrm{m}$ in

392 diameter (Plates 1K-L) within wedge-shaped planar or low angle crossed laminations. Oolites

393 are dominantly composed of multiple-coated and tangentially arranged laminations with

394 either calcite or quartz in the cortex. Intergranular pores are occluded either by lighter- 
F. Delpomdor, S. Schröder, A. Préat, P. Lapointe, C. Blanpied

395 coloured drusy sparry calcite cements, or by micro- to megacrystalline quartz cements.

396 Desiccation cracks and rare lamellar and meniscus sparry cements are present.

397 This lithofacies association represents oolitic sands deposited on beach separating the

398 supratidal mudflat and sabhka sediments from the evaporitic lagoon. Our interpretation is

399 similar to the depositional model of the stratigraphically-equivalent oolitic shoals in RC

400 (Alvarez, 1995). Coated grains are well sorted by tidal currents during the abrasion,

401 reworking and transport of lagoonal sediments. This grainstone lithofacies is also periodically

402 subjected to subaerial exposures with desiccation cracks.

403

Lithofacies association C3 (LFA-C3)

405

Lithofacies association C3 consists of microbially laminated mudstone (MF10). MF 10 is

407 dark gray, submillimetric, irregular and continuous, thin microbially laminated, planar and wavy parallel limestone. In thin section, the microfacies displays dark brown microcrystalline micritic laminations in light dark gray-brown micritic or neomorphosed microsparitic matrix

(Plate $1 \mathrm{M})$. Fenestrae characterized by small spar-filled cavities and larger irregular voids are

411 present. Platy rectangular laths of replaced gypsum, stratabound nodules and enterolitic

412 structures filled by calcite pseudomorphs of anydrite are also visible. Subvertical desiccation

413 cracks, locally forming in-situ breccias, filled by sparry cements cut-across the microbial

414 laminations.

415 The lithofacies association C3 represents shallow inter- to supratidal settings in evaporitic

416 environments. Fenestrae and desiccation cracks indicate episodic subaerial exposures in

417 intertidal settings (Grotzinger, 1986; Pratt et al., 1992). 
F. Delpomdor, S. Schröder, A. Préat, P. Lapointe, C. Blanpied

421 Lithofacies association C4 only includes the evaporitic dolomudstone microfacies (MF11).

422 This microfacies is a mud-supported dark-grey dolomitic limestone dominantly composed of

423 brownish to bluish white nodular anhydrite and interbeds of anhydrite. Anhydrite is

424 commonly replaced by a light drusy sparry cement, but microcrystals of anhydrite are

425 occluded in these cements. Various types of gypsum crystals such as lenticular, lozenge-

426 shaped, swallowtail twinned, and platy rectangular forms are fairly common (Plates $1 \mathrm{M}-\mathrm{O}$ ).

427 Small-sized nodules and chicken-wire structure show loosely packed aggregates of tiny platy

428 rectangular laths and stellate crystals (Plate $1 \mathrm{~N}$ ). Locally, 1-2 cm-thick ayers of massive

429 anhydrites are mixed with dolomudstone. The matrix is composed of equigranular xeno- to

430 hypidiotopic dolomitic crystals (5-15 $\mu \mathrm{m}$ in size) in non-planar fabrics. Desiccation cracks

431 (20-200 $\mu \mathrm{m}$ of width) filled by drusy sparry cements, and hardgrounds are also present.

432 This lithofacies association represents supratidal evaporitic environments. Such sediments are

433 encountered in the recent shallow peritidal shelf and coastal sabkha of Abu Dhabi (Shearman,

434 1978). Lenticular, swallowtail twins and lath patterns are indicative of saline intertidal

435 diagenesis (Cadwell, 1976) while nodules and chicken-wire structures are common in sabkha

436 and are the result of the replacement of gypsum by anhydrite crystals in soft sediments by

437 capillarity- dehydration processes (Kinsman, 1969). Periodical emersions were recorded and

438 form polygonal desíccation cracks or non-deposition throughout inter- and supratidal

439 beachrocks (see lithofacies association C5 for explanation).

$441 \quad$ Lithofacies association C5 (LFA-C5)

443 In the C5 Formation, the lithofacies association C5 is rare, and only includes the calcrete

444 microfacies (MF12). MF12 consists of dark, rarely yellowish-orange, millimetric-thick crusts 
F. Delpomdor, S. Schröder, A. Préat, P. Lapointe, C. Blanpied

445 of slightly undulated laminations, and in-situ brecciation of dolomitized limestone. Abundant

446 desiccation cracks are also common. In thin section, the microfacies shows light grey brown

447 fine- to medium-grained dolomitic mudstone, locally dolomitized wackestone with coated

448 grains, composed of oolites and peloids, with dense dolomicrite concentrated into crusts

449 (Plate 10). Veins of sparite form an in-situ brecciation. Sand-sized dense dolomicritic

450 'glaebules' and dolomicrite coatings are also associated with this microfacies. The matrix

451 exhibits hypidiotopic dolomitic crystals $(20 \mu \mathrm{m}$ in size). Rare laminations are planar parallel

452 to crossed. Calcite pseudomorphs after anhydrite (rosettes, laths, or fibrous repladed gypsum)

453 are fairly common. Meniscus sparry cements are observed on the rims of coated grains.

454 This lithofacies association is interpreted as near-surface soil horizons or paleosoils, formed

455 by the accumulation of $\mathrm{CaCO}_{3}$ and the oxidation of beachrock surfaces by iron hydroxides in

456 semi-arid climate conditions under sparse rainfall (Adatte et al., 2005). Occurrences of

457 evaporites and brecciation indicate that the sediment was affected by desiccation, emersion,

458 and periods of dissolution. Such processes are common in supratidal and continental

459 environments. The presence of meniscus sparry cements indicates vadose conditions.

Depositional framework interpretation

The lithofacies associations (LFA-H1 to LFA-H4 and LFAC1 to LFA-C5) of the Hüttenberg and C5 successions integrate the variations in sea level, energy and salinity in the carbonate ramp. In both the Hüttenberg and C5 formations, lithofacies associations are arranged in up to

4664 m-thick depositional cycles showing an upsection trend from marine to restricted

467 deposition, which is broadly followed by an upsection increase in energy level (Figure 7). The

468 lithofacies associations comprise six main belts described here from a distal to proximal

469 gradient recording the different levels of the hydrodynamic energy: (i) microbial 'mounds', 
F. Delpomdor, S. Schröder, A. Préat, P. Lapointe, C. Blanpied

470 (ii) stromatolitic reefs, (iii) ooid-barrier shoals, (iv) evaporitic brackish lagoons, (v) beaches 471 and (vi) coastal sabkhas (Figure 8). The type-1 cycle is characterized by a LFA-H1 to LFA-

472 H4 succession of lithofacies associations, while the type-2 cycle contains a LFA-C1 to LFA-

473 C5 succession.

474 The gradual transitions between lithofacies associations and the general increase of

475 depositional energy upsection, suggest that both formations represent deposition in a mid-to

476 inner carbonate homoclinal ramp. A beach-barrier/island-lagoon model could be applied to

477 both successions, due to the moderate to high wave energy, a relatively high tidal range

478 estimated at $\sim 1.8 \mathrm{~m}$ for the C5 Formation (see Delpomdor et al., 2018), a high carbonate sand

479 production, and the high contents of evaporites. An oolitic sand shoal-barrier separated an

480 open-marine sea with stromatolitic pinnacle reefs from a back-reef carbonate-evaporitic

481 lagoon bordered by a coastal sabkha plain (Figure 8).

482 The assemblage of lithofacies associations LFA-H1 and LFA-H2 form the lower domain of

483 the middle carbonate ramp, and records low- to moderate-energy open-marine conditions as

484 revealed by the lime mud content and the microbial patch mounds deposited on gently

485 dipping slopes. Cyanobacterial micro-organisms were associated with outer ramp LLH-type

486 stromatolitic buildups forming small-scale mounds and pinnacles (LFA-H3). These

487 stromatolites grew in moderate- to high-energy shallow waters around an active wave base.

488 The ooid shoal lithofacies (LFA-H4) form a barrier island, and represent high-energy

489 sediments related to tidal and wave agitation. The ooids indicate 'warmer' and possibly

490 aragonite-saturated waters, preferentially dolomitized by brines percolating from the lagoonal

491 and evaporitic environments during dry to arid climatic episodes (van Smeerdijik Hood and

492 Wallace, 2018). The middle-inner carbonate ramp profile and its geometry are observed on

493 homoclinal shelf margins of other Neoproterozoic successions (Batten et al., 2004: Cozzi et

494 al., 2004; Thomson et al., 2014). 
F. Delpomdor, S. Schröder, A. Préat, P. Lapointe, C. Blanpied

495

496

The Hüttenberg units of our study were deposited in the post-rift Khomas sea along the southern margin of the Congo Craton. They represent the development of a shallow-water carbonate epicontinental platform (Stanistreet et al., 1991; Kamona and Günzel, 2007).

However, the presence of dessication cracks and breccia indicates that during deposition, the sediment was periodically subjected to subaerial exposure. Locally, lagoonal sediments were affected by to hypersaline conditions, with microbial mats, evaporites (horizons of $9-14 \mathrm{~m}$ of thickness) and cherts resulting (Kamona and Günzel, 2007). These conditions are confirmed by typical marine REE $+\mathrm{Y}$ signatures, and highly variable enrichment in ${ }^{13} \mathrm{C}$ (reaching several plateaux of $+8 \%$ to $+12 \%$ ) due to elevated evaporation rates in a restricted basin (Frimmel, 2009, 2010).

In the C5 Lukala Formation, the lagoonal belt shows a typical blackened dolomitized limestone lithofacies association (LFA-C1 to $-\mathrm{C} 4)$ with a relatively high organic content suggesting possible periods of dysoxia/anoxia in the lagoon. The reducing waters were followed by well-oxygenated waters, which facilitated the development of benthic cyanobacterial mats in the nearshore zones of the lagoon. The coastal shoreline zone (LFAC3) was marked by waves, tides and elevated salinity. Off-shore sand bars on a beachstrandplain belt were probably dominated by high wave energy and low tidal range as shown by ripples, cross laminations, and reworking and transport of cyanobacteria fragments living in the foreshore and backshore environments. Beachrock formed due to rapid cementation of sand-sized grains by aragonite and Mg-calcite crystals growing in the interparticular spaces. Beachrock is a common feature of low-latitude warm-water beaches in tropical and temperate environments and formed during cessation of sedimentation or periods of low sedimentation rate (Scoffin and Stoddard, 1983). The sabkha evaporites, dolomitization, and caliche crusts (LFA-C4 to -C5) can be used as paleoclimatic markers of semi-arid normally low-latitude deposition. The evaporites, dolomitization, and caliche crusts (LFA-C4 to -C5), point to an 
F. Delpomdor, S. Schröder, A. Préat, P. Lapointe, C. Blanpied

520

521

522

523

524

525

526

527

528

529

530

531

532

533

arid climate of deposition instead. Extensive dolomitization, locally capped by caliche surfaces at the top of evaporitic cycles, occurred between the coastal and the reefal zones. The upper parts of sections of the carbonate-evaporitic lagoon were seasonally subjected to precipitation with formation of caliche surfaces, containing vadose pisoids, pseudo-peloids, and breccias.

The distribution of open-marine type-1 cycle of the Hüttenberg Formation follows a thin peritidal cycle with an average cycle thickness of approximately $4 \mathrm{~m}$ (in this paper), while the type-2 cycle of the C5 Formation shows an average thickness of $\sim 1.8 \mathrm{~m}$ (Delpomdor et al., 2018). Such thicknesses are frequent in peritidal environments (Catuneanu et al., 2011; Franseen and Byrnes, 2012; Delpomdor et al., 2015). The open-marine type-1 cycle of the Hüttenberg Formation preludes the lagoonal and near-shore type-2 cycle of the C5 Formation, and locally present in the T8 unit of the Hüttenberg Formation. Although the Hüttenberg Formation and the C5 Formation were deposited in two distinct basins on the southwestern and western margin of the C-SF cratons, there are similar patterns of lithofacies associations that reflect similar deposition on passive margins during the global post-Marinoan sea-level transgression.

\section{Carbon and strontium isotopes}

The carbon and strontium isotopic data for the C5 Formation (DRC) are shown in Table 2. Analysis of major and trace elements demonstrate that the samples retained their original marine isotope signature (Delpomdor and Préat, 2013). Carbon isotope data for the Hüttenberg Formation from a previous study on Tsumeb core S86A (Kaufman et al., 2010) are compared with our results for stratigraphic correlation. 
F. Delpomdor, S. Schröder, A. Préat, P. Lapointe, C. Blanpied

544 The $\mathrm{C} 5 \mathrm{a} / \mathrm{C} 5 \mathrm{~b}$ boundary is marked by a positive shift in $\delta^{13} \mathrm{C}$ values from $+1.5 \%$ to $+7.5 \%$,

545 followed by an upwards-decrease in $\delta^{13} \mathrm{C}$ values from $+7.5 \%$ to $+1.3 \%$. A second positive

546 shift occurs in the middle $\mathrm{C} 5 \mathrm{~b}$, with $\delta^{13} \mathrm{C}$ values varying from $+1.3 \%$ to $+10.8 \%$, followed by

547 a significant upwards-decreasing of $\delta^{13} \mathrm{C}$ until $+3.1 \%$. The $\mathrm{C} 5 \mathrm{~b} / \mathrm{upper} \mathrm{C} 5 \mathrm{~b}$ boundary is

548 marked by positive isotopic shift in $\delta^{13} \mathrm{C}$ from $+3.1 \%$ to $+5.6 \%$ directly overlain by a rapid

549 return to negative isotopic shift in $\delta^{13} \mathrm{C}$ around $+1.7 \%$. The upper $\mathrm{C} 5 \mathrm{~b}$ Formation displays

550 higher $\delta^{13} \mathrm{C}$ values than the $\mathrm{C} 5 \mathrm{a}$ and $\mathrm{C} 5 \mathrm{~b}$ formations with a mean value ranging around

$551+6.2 \%$. At the top of the succession $\delta^{13} \mathrm{C}$ values fall sharply to near $+3.5 \%$, just before being

552 truncated by the molasse of the Mpioka Subgroup in this part of the DRC. One sample of the

553 C5b Formation has a strontium isotope ratio of 0.7081 , while ${ }^{87} \mathrm{Sr}{ }^{86} \mathrm{Sr}$ ratios in the upper C5b

554 Formation range between 0.7084 and $0.7090(\mathrm{n}=2)$. Oyerall ${ }^{87} \mathrm{Sr} /{ }^{86} \mathrm{Sr}$ ratios are altered by

555 diagenetic fluids directly after deposition, as evidenced by the low $\mathrm{Sr}$ concentrations above

556 the cut-off of $300 \mathrm{ppm}$ (Halverson et al., 2007), and cannot therefore be used as a proxy for

557 correlation (Delpomdor et al., 2018). However, samples from the same unit published by

558 Frimmel et al. (2006), close of the cut-gff of $300 \mathrm{ppm}$ plot in the same ${ }^{87} \mathrm{Sr} /{ }^{86} \mathrm{Sr}$ ranges

$559(0.7074-0.7075)$ and are considered as unaltered samples, representative of the seawater

560 composition.

561 The Hüttenberg Formation carbonates revealed a significantly higher positive carbon isotope

562 excursion thạn at any other time in the Neoproterozoic Era (Kaufman et al., 2010). The lower

563 part of the Huttenberg Formation shows a range of values between $+8 \%$ ond $+10 \%$. The

564 middle and upper parts are marked by isotopic shifts of $\delta^{13} \mathrm{C}$ values from $+12 \%$ to $+4 \%$ and

565 from $+10 \%$ to $+2 \%$ respectively. The lowest $\delta^{13} \mathrm{C}$ values between $+0 \%$ and $+2 \%$ are

566 encountered in the middle part of this unit. ${ }^{87} \mathrm{Sr} /{ }^{86} \mathrm{Sr}$ ratios in the Hüttenberg Formation range

567 between 0.7076 and $0.7086(n=2)$ with Sr concentrations between 60 and $1220 \mathrm{ppm}(\mathrm{n}=2)$

568 (Frimmel et al., 1996). 
F. Delpomdor, S. Schröder, A. Préat, P. Lapointe, C. Blanpied

569 The $\delta^{13} \mathrm{C}$ data of both Hüttenberg and C5 formations are significant with the carbon isotopic

570 values published by Frimmel et al. (1996) and Halverson et al. (2005), in the same range.

\section{Stratigraphic correlations}

Current regional correlations of Cryogenian and Ediacaran glaciogenic successions in central east Brazil, northwestern Namibia and west central DRC rely on chemostratigraphic and radiometric age constraints (Figure 10; Pedrosa-Soares et al., 2008; Kaufman et al., 2010; Tait et al., 2011; Caxito et al., 2012; Cailteux et al., 2015). Numerous correlations between the carbonate successions of the Bambuí Group (central east Brazil; 750->540 Ma in age) and 579 the West Congo Supergroup (west central DRC) have been suggested (Alkmim and Martins580 Neto, 2012; Caxito et al., 2012; Cailteux et al., 2015) but are hampered by lack of precise 581 radiometric dating of both successions (Santos efal., 2000; Caxito et al., 2012; Paula-Santos 582 et al., 2017). Both sedimentary successions are considered as coeval with the Damara 583 Supergroup (Cailteux et al., 2015). Based on lithostratigraphic and radiometric data, the 584 Tsumeb Subgroup in Namibia and the Gombela Subgroup of the Central Africa Copperbelt 585 (CAC) in DRC and Zambia were considered as coeval (Miller, 2013). The Tsumeb Subgroup 586 succession is constrained by an $\mathrm{U}-\mathrm{Pb}$ zircon age of $635 \pm 1.2 \mathrm{Ma}$ on an ash layer interbed in 587 the Ghaub Formation (Hoffmann et al., 2004), and U-Pb detrital zircon ages on 588 metasediments between $606 \pm 24 \mathrm{Ma}$ and $587 \pm 9 \mathrm{Ma}$ in the Kuiseb Formation (Foster et al., 589 2015; Eehmann et al., 2016), considered as stratigraphic-equivalent with the Hüttenberg 590 Formation (Miller, 2008). The youngest age is confirmed by ${ }^{40} \mathrm{Ar}-{ }^{39} \mathrm{Ar}$ metamorphic ages of 591590 Ma obtained in the Kuiseb Formation (Lehmann et al., 2016). A minimum deposition age 592 for the top of the Swakop Group in Northern Zone of Namibia, intruding the Karibib and 593 Kuiseb formations, is constrained by granite and metamorphic age determinations of $\sim 585-$ 
F. Delpomdor, S. Schröder, A. Préat, P. Lapointe, C. Blanpied

594

$570 \mathrm{Ma}$ (Bergemann et al., 2014; Milani et al., 2014; Forster et al., 2015). In the CAC, the oldest metamorphic ages are $592 \pm 22 \mathrm{Ma}(\mathrm{U}-\mathrm{Pb}$ monazite) and $585.8 \pm 0.8 \mathrm{Ma} \mathrm{Ar}-\mathrm{Ar}$ plateau age for biotite (Rainaud et al., 2005). Recently, Cailteux et al. (2015) correlated the lower part of the Lukala Subgroup (C1-C3 formations) of the West Congo Supergroup with the Gombela Subgroup, which displays a strongly comparable sedimentary succession, in particular the similarity between the oolitic limestone of the Lubudi and C3 formations. However, this correlation is still debated due to the lack of chemostratigraphic and radiometric constraints.

In the absence of temporally significant fossils and radiometric constraints, carbon isotope stratigraphy was specifically applied to the correlation of carbonates above and below the Namibian "Marinoan-age” glacial deposits, e.g., Ghaub Formatiøn (Kaufman et al., 1991).

\section{Composite carbon-isotope profiles spanning the inferred Marinoan and Pan-African} deformation events in northwestern Namibia, west central DRC, and central east Brazil show two carbon-isotope trends. The first trend (arrow 1) is marked by a positive to negative shift in $\delta^{13} \mathrm{C}$ values in the dolostones of the Maieberg in Namibia and $\mathrm{C} 1$ formations in DRC, and the Pedro Leopoldo Member, lowermost unit of the Sete Lagoas Formation in Brazil (Santos et al., 2000; Halverson et al. 2005; Straathof, 2011; Caxito et al., 2012; Delpomdor and Préat, 2013; Cailteux et al., 2015; Paula-Santos et al., 2017). This isotopic "event" is followed by a positive excursion in $\delta^{13} \mathrm{C}$ values, which is marked by a rapid marine transgression as a result of extensional tectonic processes directly after the Marinoan-age glaciation event (Halverson et al., 2005; Delpomdor et al., 2016; Caxito et al., 2012; Paula-Santos et al., 2017). Such glaciations are recorded in the Ghaub Formation in Namibia, Jequitaí Formation in Brazil, and periglacial deposition in the Niari Formation in Gabon, stratigraphic-equivalent of the distal gravity deposited sediments in the Upper Diamictite Formation in DRC (Prian et al., 2009; Busfield and Le Heron, 2013; Uhlein et al. 2013, 2016; Delpomdor et al., 2016, 2017; 
F. Delpomdor, S. Schröder, A. Préat, P. Lapointe, C. Blanpied

619 Nascimento et al., 2016; Rodler et al., 2017). The second trend (arrow 2) is marked by a

620 negative to positive excursion in $\delta^{13} \mathrm{C}$ values in the Elandshoek and Hüttenberg formations in

621 Namibia, comparable to carbon-isotope values of the C4 and C5 formations in DRC and the

622 upper part of the Sete Lagoas (Santa Lagoa Member) to Lagoa do Jacaré formations in Brazil

623 (Kaufman et al., 1991, 2010; Frimmel et al., 1996; Santos et al., 2000; Halverson et al., 2005;

624 Frimmel et al., 2006; Straathof, 2011; Caxito et al., 2012; Delpomdor and Préat, 2013;

625 Cailteux et al., 2015; Paula-Santos et al., 2017; Delpomdor et al., 2018). The contact between

626 the $\mathrm{C} 3 / \mathrm{C} 4$ formations in DRC, as well as in the stratigraphic-equivalent SCI-SCII in the

627 Republic of Congo (A.P-. Ackouala, 2018, pers. comm.), shows abrupt lithological changes

628 and negative carbon-isotope shift related to a possible Gaskiers-age event (Cailteux et al.,

629 2015; Delpomdor et al., 2018). The second carbon-isotope trend corresponds to a second

630 marine transgression, which flooded the Damara, West Congo, and São Francisco basins in

631 Namibia, DRC and Brazil respectively (Martins-Aeto et al., 2001; Cailteux et al., 2015; Préat

632 et al., 2011; Reis and Alkmim, 2015; Delpomdor et al., 2018). This transgression eventually

633 gave rise to a restricted basin without an efficient mixing with external seawater. Because of

634 the stagnant dysoxic to anoxic water columns the organic matter was preserved in the

635 evaporitic shallower environments (e.g., the Hüttenberg, C5, and Lagoa do Jacaré

636 formations). We suggest that the second marine transgression favoured regional-scale

637 exchange with other basins accompanied by flora migration and development of benthic

638 helicoidal cyanobacteria Obruchevella parva in the C5 Formation (Alvarez et al., 1995;

639 Delpomdor et al., 2018) and Cloudina and Corumbella in the Sete Lagoas Formation (Warren

640 et al., 2015), and unknown cyanobacterial organisms in the Hüttenberg Formation (this

641 study). Obruchevella parva is commonly considered as an index fossil for the terminal

642 Ediacaran (Yakschin and Luchinina, 1981) or Cambro-Ordovician (Reitlinger, 1959).

643 Cloudina and Corumbella are considered as index fossils for the terminal Ediacaran (Warren 
F. Delpomdor, S. Schröder, A. Préat, P. Lapointe, C. Blanpied

644 et al., 2015), which is recently supported by maximum deposition ages (U-Pb zircon dating)

645 of $\sim 557$ Ma for most of the Sete Lagoas Formation (Paula-Santos et al., 2015). Although the

646 index fossil Cloudina is absent in the C5 and Hüttenberg formations, probably due to a later

647 closure of the marine interconnection between the C-SF and Kalahari cratons, the abundance

648 of cyanobacterial organisms might be considered as a coeval biological marker for

649 stratigraphic correlations between the uppermost parts of the Sete Lagoas to Lagoa do Jacaré

650 formations, and the C5 Formation (Cailteux et al., 2015; Delpomdor et al., 2018), thereby,

651 allowing the debatable Late Ediacaran age (e.g., 580-540 Ma) of the Hüttenberg Formation to

652 be applied to the Sete Lagoas and Lagoa do Jacaré formations.

653 In this paper, $\delta^{13} \mathrm{C}$ values of the $\mathrm{C} 5$ and Lagoa do Jacaré carbonates are compared with the

654 carbon isotope values from the Tsumeb core S86A, (Kaufman etal., 1991) (Figures 9 and 10),

655 and the published data from Halverson et al. (2005). The C5 Formation shows seven upwards-

656 increasing trends of $\delta^{13} \mathrm{C}$ that may be correlated the lower and middle parts of the

657 Hüttenberg Formation. A distinct negative shift of $\delta^{13} \mathrm{C}$ values at the top of the Hüttenberg

658 Fornmation is currently not recognized at the top of the C5 Formation due to lack of data

659 resulting from erosion by the Mpioka Subgroup (Figure 9). This negative $\delta^{13} \mathrm{C}$ shift can be

660 correlated to the Gaskiers (580 Ma) or Moelv (560 Ma) isotope shifts linked to the Numees

661 Formation diamictite in southern Namibia (Kaufman et al., 1991), or to the Basal Cambrian

662 Isotope Excurrsion (BACE; see Alvaro et al., 2008). In Brazil, the Lagoa do Jacaré Formation

663 shows comparable $\delta^{13} \mathrm{C}$ values, to the Hüttenberg and C5 formations (Figure 10).

664 All formations are overlain by molasse-type sediments related to the collision of the Rio de la

665 Plata Craton with the C-SF cratons and closure of the Adamastor Ocean along the 575-540

666 Kaoko-Gariep-Araçuaï-West Congo belts (e.g. Frimmel and Frank, 1998; Frimmel et al.,

667 2006; Konopásek et al., 2014; Merdith et al., 2017), and the closure of the Khomas Ocean 
F. Delpomdor, S. Schröder, A. Préat, P. Lapointe, C. Blanpied

668 between C-SF and Kalahari cratons around 550 Ma with the development of the Damara-

669 Lufilian-Zambezi Orogen (e.g. Naydenov et al., 2014; Merdith et al., 2017).

670 Independent of the absolute ages, the similarity in chemostratigraphy, their similar

671 stratigraphic position, sedimentology and sea level evolution, suggest that Hüttenberg and C5

672 formations might be coeval deposits on the margins of the C-SF cratons. In this paper, we

673 consider the age of the C5 Formation, and its stratigraphic-equivalent Hüttenberg Formation,

674 as terminal Ediacaran (e.g., 580-540 Ma). However, the current knowledge of the depositional

675 ages of these sedimentary successions through the Damara and West Congo basins is very

676 limited which limits more precise prediction of stratigraphic correlations.

677

678 Conclusions

679

680 New descriptions and sedimentological study of Rey cores and outcrops in the Hüttenberg

681 Formation in northwestern Namibia show that this unit formed in an open-marine mid-inner

682 carbonate ramp setting with organic mounds, pinnacles and oolitic shoal-barrier islands. The

683 mid ramp includes shallow-water microbial and stromatolitic patch mounds and pinnacles,

684 respectively, formed on gentle slopes at the outer edges of the shelf on the southern margin of

685 the Congo-São Francisco cratons. Inner ramp deposits are composed of oolitic shoals and

686 lagoonal muds, locally subjected to hypersaline conditions, behind a wide gently sloping

687 shelf. Sedimentology establishes similar lithofacies associations in the C5 Formation of the

688 Democratic Republic of Congo, with four main belts recording different levels of

689 hydrodynamic energy following a distal to proximal gradient from: (i) an ooid-barrier shoal,

690 (ii) an evaporitic brackish lagoon, (iii) a beach, and finally (iv) a coastal sabkha.

691 The carbonate ramp represented by the Hüttenberg Formation is considered as regionally

692 correlative of the C5 carbonates. In term of geochronology, the Hüttenberg Formation is 
F. Delpomdor, S. Schröder, A. Préat, P. Lapointe, C. Blanpied

693 constrained by U-Pb zircon ages of $\sim 635 \mathrm{Ma}$ and $\sim 590 \mathrm{Ma}$ in the Ghaub and Kuiseb

694 formations in Central Namibia. Due to the lack of radiometric data in the Tsumeb Subgroup

695 in northwestern Namibia, carbon-isotope stratigraphy was tentatively applied to the

696 correlation as reference curves for worldwide carbonate successions (Halverson et al., 2005).

697 Two $\delta^{13} \mathrm{C}$ trends were identified as the result of a marine transgression, interconnected with

698 global extensional tectonic processes, directly after the Marinoan-age glaciation event. The

699 first carbon-isotopic trend is marked by a strong negative anomaly in $\delta^{13} \mathrm{C}$ values, followed by

700 a negative to positive excursion, probably coeval with the Maieberg Formation in Namibia,

701 the $\mathrm{C} 1$ to $\mathrm{C} 3$ formations (Kwilu unit) in DRC, and the lower part of the Sete Lagoas

702 Formation (Pedro Leopoldo Member) in Brazil. A second negative to strongly positive

703 excursion in $\delta^{13} \mathrm{C}$ values is recognized in the Elandshoek-Hüttenberg succession in Namibia,

704 comparable to the carbon-isotope values in the C4-C5 formations in DRC, and in the upper

705 part of the Sete Lagoas (Santa Lagoa Member), and Lagoa do Jacaré formations in Brazil. This

706 carbon-isotope excursion records a second marine transgression, which gave rise to regional-

707 scale exchange with other basins accompanied by flora migration and development of Late

708 Ediacaran benthic cyanobacterial micro-organisms, abundantly present in the Hüttenberg and

709 C5 formations. The conyergence of chemostratigraphic data and biostratigraphy suggest a

710 Late Ediacaran age-e.g., 580-540 Ma - of deposition for the both Hüttenberg and C5

711 formations, comparable to the Lagoa do Jacaré Formation in Brazil.

712

713 Acknowledgments

714

715 The authors acknowledge the Royal Museum for Central Africa (RMCA, Belgium) and Total

716 S.A. for kindly granting access to the drill core logs and outcrop sections from the C5

717 Formation in DRC, and the Hüttenberg Formation in Namibia. We thank SAJG Editor Prof. 
F. Delpomdor, S. Schröder, A. Préat, P. Lapointe, C. Blanpied

718 Dr. Stephen McCourt and reviewers Prof. Dr. Hartwig Frimmel (Universität Würzburg) and

719 Prof. Dr. Wlady Altermann (University of Pretoria) for thoughtful and constructive comments 720 and suggestions which improved the manuscript significantly.

\section{References}

Adatte, T., Keller, G., Stüben, D., Harting, M., Kramar, U., Stinnesbeck, W., Abramovich, S. and Bemjamini, C., 2005. Late Maastrichtian and K/T palaeoenvironment of the eastern Tethys (Israel): mineralogy, trace and platinum group elements, biostratigraphy and faunal turnovers. Bulletin de la Société Géologique de France, 176 (1), 37-55.

Alkmim, F.F. and Martins-Neto, M.A., 2012. Proterozoic first-order sedimentary sequences

729 of the São Francisco craton, eastern Brazil. Marine and Petroleum Geology, 33, 127-139.

730 Alkmim, F.F., Marshak, S., Pedrosa-Soares, A. C,Peres, G.G., Cruz, S. and Whittington, A.,

731 2006. Kinematic evolution of the Araçuar-West Congo orogen in Brazil and Africa:

732 Nutcracker tectonics during the Neoproterozoic assembly of Gondwana. Precambrian

733 Research, 149, 43-64.

734 Alvarez, Ph., 1995. Les facteurs de contrôle de la sédimentation du Supergroupe Ouest-

735 Congolien (Sud-Congo). Rampe Carbonatée et activité biologique au Protérozoïque 736 Supérieur.|Edition BRGM, 239, 286pp

737 Alvarez, Ph., Chauvel, J.-J. and van Vliet-Lanoë, B., 1995. Obruchevella, cyanobactérie 738 fossile du Protérozoïque supérieur du Congo. Implications sur l'âge du Groupe Schisto739 Calcaire et de la glaciation fini-Protérozoïque. Comptes Rendus de l'Académie des 740 Sciences, Serie 2, Sciences de la Terre et des Planètes, 320 (7), 639-646. 
F. Delpomdor, S. Schröder, A. Préat, P. Lapointe, C. Blanpied

Álvaro, J.J., Bauluz, B., Pierre, C., Subías, I. and Vizcaïno, D., 2008, Carbon chemostratigraphy of the Cambrian-Ordovician transition in a mid-latitude mixed platform, Montagne Noire, France. Geological Society of America Bulletin, 120, 962-975.

Armstrong, R.A., Master, S. and Robb, L.J., 2005. Geochronology of the Nchanga Granite and constraints on the maximum age of the Katanga Supergroup, Zambian Copperbelt. Journal of African Earth Sciences, 42, 32-40.

Batten, K.L., Narbonne, G.M. and James, N.P., 2004. Paleoenvironments and growth of early Neoproterozoic calcimicrobial reefs: platformal Little Dal Group, northwesfern) Canada. Precambrian Research, 133, 249-269.

Baudet, D., Kant-Kabalu, F. and Fernandez-Alonso, M., 2014. Carte géologique de la République du Congo, Province du Bas-Congo, avec notice explicative. Centre de Recherches Géologique et Minière (CRGM), Kinshasa, RDC et Musée royal de l'Afrique Centrale (MRAC), Tervuren, Belgique, ISBN 978-9-4916-1535-1.

Begg, G.C., Griffin, W.L., Natapov, L.M., O'Reilly, S.Y., Grand, S.P., O'Neill, C.J., Hronsky, J.M.A., Poudjom Djomani, Y., Swain, C.J., Deen, T. and Bowden, P., 2009. The lithospheric architecture of Africa: seismic tomography, mantle petrology, and tectonic evolution. Geosphere, 5 (1),23-50.

Bergemann, C., Jung, S., Berndt, J., Stracke, A. and Hauff, F., 2014. Generation of magnesian, high-K alkali-calcic granites and granodiorites from amphibolitic continental crust in the Damara Orogen, Namibia. Lithos, 198-199, 217-233.

Brito-Neves, B.B., Campos-Neto, M.C. and Fuck, R.A., 1999. From Rodinia to Western Gondwana: An approach to the Brasiliano-Pan African cycle and orogenic collage. Episodes, 22, 155-199.

Burchette, T.P. and Wright, V.P., 1992. Carbonate ramp depositional systems. Geology, 79, 3-57. 
F. Delpomdor, S. Schröder, A. Préat, P. Lapointe, C. Blanpied

766 Busfield, M.E. and Le Heron, D.P., 2013. Glacitectonic deformation in the Chuos Formation 767 of northern Namibia: implications for Neoproterozoic ice dynamics. Proceedings of the 768 Geologists'Association, 124 (5), 778-789.

769 Cadwell, R.A., 1976. Holocene gypsum deposits of the Bullara Sunkland, Carnavaron basin,

770 Western Australia. Unpublished PhD thesis, University of Western Australia, Perth, $771 \quad$ Australia. 123pp

772 Cailteux, J.L.H., Delpomdor, F.R.A. and Ngoie Ndobami, J.-P., 2015. The Neoproterozoic

773 West Congo 'Schisto-Calcaire” sedimentary succession from the Bas-Cong6 region

774 (Democratic Republic of the Congo) in the frame of regional tentative correlations.

775 Geologica Belgica, 18 (2-4), 126-146.

776 Catuneanu, O., Galloway, W.E., Kendall, C.G.S.C., Miall, A.D., Posamentier, H.W., Strasser, 777 A. and Tucker, M.E., 2011. Sequence Stratigraphy: Methodology and Nomenclature.

778 Newsletters on Stratigraphy, 44 (3), 173-245,

779 Caxito, F.A., Halverson, G.P., Uhlein, A., Steyenson, R., Dias, T.G. and Uhlein, G.J., 2012.

780 Marinoan glaciation in east centra/Brazil. Precambrian Research, 200-203, 38-58.

781 Clauer, N. and Kröner, A., 1979. Strontium and argon isotopic homogenization of pelitic

782 sediments during low-grade regional metamorphism: the Pan-African upper Damara

783 sequence of Northern Namibia (SouthWest Africa). Earth and Planetary Science Letters, 43,

$784 \quad 117-131$

785 Collins, A.S. and Pisarevsky, S.A., 2005, Amalgamating eastern Gondwana: The evolution of 786 the circum-Indian orogens. Earth-Science Reviews, 71, 229-270.

787 Cordani, U.G., Brito-Neves, B.B., D’Agrella, M.S. and Trindade, R.I.F., 2003. Tearing-up 788 Rodinia: the Neoproterozoic paleogeography of South American cratonic fragments. Terra $789 \quad$ Nova, 15, 343-349. 
F. Delpomdor, S. Schröder, A. Préat, P. Lapointe, C. Blanpied

Cozzi, A., Grotzinger, J.P. and Allen, P.A., 2004. Evolution of a terminal Neoproterozoic carbonate ramp system (Buah Formation, Sultanate of Oman): Effects of basement paleotopography. Geological Society of America Bulletin, 116 (11-12), 1367-1384.

Delpomdor, F. and Préat, A., 2013. Early and Neoproterozoic C, O and Sr isotope chemostratigraphy in the carbonates of West Congo and Mbuji-Mayi supergroups: A preserved marine signature? Palaeogeography, Palaeoclimatology, Palaeoecology, 389, 3547.

Delpomdor, F., Tack, L., Cailteux, J. and Préat, A., 2015. The C2 and C3 formations of the Schisto-Calcaire Subgroup (West Congo Supergroup) in the Democratic Republic of the Congo: An example of post-Marinoan sea-level fluctuations as a result of extensional tectonisms. Journal of African Earth Sciences, 110, 14-33.

Delpomdor, F., Eyles, N., Tack, L. and Préat, A., 2016. Pre- and post-Marinoan carbonate facies of the Democratic Republic of the Congo. Glacially- or tectonically-influenced deepwater sediments? Palaeogeography, Palaeoclimatology, Palaeoecology, 457, 144-157.

Delpomdor, F.R.A., Tack, L. and Préat, A.R., 2017. Facies and micromorphology of the Neoproterozoic Upper Diamictite Formation in the Democratic Republic of Congo: new evidence of sediment gravity flow. Geologica Belgica, 20 (1-2), 69-79.

Delpomdor, F., Van Vliet, N., Devleeschouwer, X, Tack., L. and Préat, A., 2018. Evolution and Estimated Age of the C5 Lukala Carbonate-Evaporite Ramp Complex in the Lower Congo region (Democratic Republic of Congo): New perspective in Central Africa. Journal of African Earth Sciences, 137, 261-277.

Flügel, E., 2010. Microfacies of Carbonate Rocks, Analysis Interpretation and Application, Springer-Verlag, Berlin, Heidelberg. 976pp

Foster, D.A., Goscombe, B.D., Newstead, B., Mapani, B., Mueller, P.A., Gregory, L.C. and Muvangua, E., 2015. U-Pb age and Lu-Hf isotopic data of detrital zircons from the 
F. Delpomdor, S. Schröder, A. Préat, P. Lapointe, C. Blanpied

815 Neoproterozoic Damara Sequence: implications for Congo and Kalahari before Gondwana.

816 Gondwana Research, 28, 179-190.

817 Franseen, E.K. and Byrnes, A.P., 2012. Arkuckle Group Platform Strata in Kansas: A

818 synthesis. In: J.R. Derby, R.D. Fritz, S.A. Longacre, W.A. Morgan and C.A. Sternbach

819 (Editors.), The great American carbonate bank. The geology and economic resources of the

820 Cambrian-Ordovician Sauk megasequence of Laurentia. American Association of

821 Petroleum Geologists Bulletin, Memoir 98, 1031-1047.

822 Frimmel, H.E., 2009. Trace element distribution in Neoproterozoic carbonates as)

823 palaeoenvironmental indicator. Chemical Geology, 258 (3-4), 338-353.

824 Frimmel, H.E., 2010. On the reliability of stable carbon isotopes for Neoproterozoic

825 chemostratigraphic correlation. Precambrian Research, 182 (4), 239-253.

826 Frimmel, H.E. and Frank, W., 1998. Neoproterozoic tectono-thermal evolution of the Gariep

827 Belt and its basement, Namibia and South Africa. Precambrian Research, 90 (1), 1-28.

828 Frimmel, H.E., Deane, J.G. and Chadwick, P.J., 1996. Pan-African tectonism and the genesis

829 of base metal sulfide deposits in the northern foreland of the Damara Orogen, Namibia. In:

830 D.F. Sangster (Editor), Carbonate-Hosted Lead-Zinc Deposits. Society of Economic

831 Geologists, Special Publication No. 4, 204-217.

832 Frimmel, H.E., Tack, L., Basei, M.S., Nutman, A.P. and Boven, A., 2006. Provenance and

833 chemostratigraphy of the Neoproterozoic West Congolian Group in the Democratic

834 Republic of Congo. Journal of African Earth Sciences, 46, 221-239.

835 Gerdes, G., Dunajtschik-Piewak, K., Riege, H., Taher, A.G., Krumbein, W.E. and Reineck,

836 H.E., 1994. Structural diversity of biogenic carbonate particles in microbial mats.

837 Sedimentology, 41, 1273-1294.

838 Germs, G.J.B., Miller, R.McG., Frimmel, H.E. and Gaucher, C., 2009. Syn- to late-orogenic

839 sedimentary basins of southwestern Africa. Neoproterozoic to Early Palaeozoic evolution of 
F. Delpomdor, S. Schröder, A. Préat, P. Lapointe, C. Blanpied

840 Southwestern Africa. In: C. Gaucher, A.N. Sial, G.P. Halverson and H.E. Frimmel

841 (Editors), Neoproterozoic-Cambrian Tectonics, Global Change and Evolution: A Focus on

842 Southwestern Gondwana. Developments in Precambrian Geology, volume 16, Elsevier, 843 183-203.

844 Grotzinger, J.P., 1986. Cyclicity and paleoenvironmental dynamics, Rocknest platform,

845 northwestern Canada. Geological Society of America Bulletin, 97, 1208-1231.

846 Halverson, G.P., Dudas, F.O., Maloof, A.C. and Bowring, S.A., 2007. Evolution of the

$847{ }^{87} \mathrm{Sr} /{ }^{86} \mathrm{Sr}$ composition of Neoproterozoic seawater. Palaeogeography, Palaeoclimatology, 848 Palaeoecology, 256, 103-129.

849 Halverson, G.P., Hoffman, P.F., Schrag, D.P., Maloof, A.C. and Rice, A.H.N., 2005. Towards 850 a Neoproterozoic composite carbon isotope record. Geological Society America Bulletin, $851 \quad 117,1181-1207$.

852 Hedberg, R.M. 1979. Stratigraphy of the Ovambdand Basin, South West Africa. Bulletin of 853 Precambrian Research Unit, volume 24, Uniyersity of Cape Town, Cape Town, South $854 \quad$ Africa. $325 \mathrm{pp}$

855 Hoffman, P.F., 1999. The break-up of Rodinia, birth of Gondwana, true polar wander and the 856 Snowball Earth. Journal of African Earth Sciences, 28 (1), 17-33.

857 Hoffman, P.F. and Schrag, D.P., 2002. The snowball Earth hypothesis: testing the limits of 858 global change. Terra Nova, 14, 129-155.

859 Hoffman, P.F., Swart, R., Eckhardt E.F. and Guowei, H. 1994. Damara orogen of northwest 860 Namibia. Geological Excursion Guide Geological Survey of Namibia, 55 p.

861 Hoffman, P., Kaufman, A., Halverson, G. and Schrag, D., 1998. A Neoproterozoic snowball $862 \quad$ Earth. Science, 281, 1342-1346. 
F. Delpomdor, S. Schröder, A. Préat, P. Lapointe, C. Blanpied

863

864

865

866

867

868

869

870

871

872

873

874

875

876

878

879

880

881

882

883

884

885

886

Hoffmann, K.H. and Prave, A.R., 1996. A preliminary note on a revised subdivision and regional correlation of the Otavi Group based on glaciogenic diamictites and associated cap dolostones. Communication of the Geological Survey of Namibia, 11, 77-82.

Hoffmann, K.H., Condon, D.J., Bowring, S.A., and Crowley, J.L., 2004. A U-Pb zircon date from the Neoproterozoic Ghaub Formation, Namibia: Constraints on Marinoan glaciation. Geology, 32, 817-820.

James, N.P and Ginsburg R.N., 1979. The seaward margin of Belize barrier and atoll reefs International Association of Sedimentology, Special Publication, volume 3.173pp

Kamona, A.F. and Günzel, A., 2007. Stratigraphy and base metal mineralization in the Otavi Mountain Land, Northern Namibia - a review and regional interpretation. Gondwana Research, 11, 396-413.

Kant-Kabalu, F., Kadja-Wongudi, G., Mujinga-Mulemba, E., Nseka-Mbemba, P., PhambuLandu, J., Kanda-Nkula, V., Baudet, D., Dewaele, S., Eekelers, K., Fernandez, M., Laghmouch, M., Theunissen, K. and Tack, L., 2016. New 1/500.000 scale GIS-based geological and mineral resources maps for Bas-Congo province (DRC) with an updated lithostratigraphy of the Neoproterozoic West Congo Supergroup. $5^{\text {th }}$ International Geologica Belgica 2016 Congress, University of Mons, Mons, Belgium, 42-43.

Kaufman, A.J., Hayes, J.M., Knoll, A.H. and Germs, G.J.B., 1991, Isotopic compositions of carbonates ánd organic carbon from upper Proterozoic successions in Namibia:

Stratigraphic variation and the effects of diagenesis and metamorphism. Precambrian Research 49, 301-327.

Kaufman, A.J., Sial, A.N., Frimmel, H.E. and Misi, A., 2010, Neoproterozoic to Cambrian Paleoclimatic Events in Soutwestern Gondwana. In: C. Gaucher, A.N. Sial, G.P. Halverson and H.E. Frimmel (Editors), Neoproterozoic-Cambrian Tectonics, Global Change and 
F. Delpomdor, S. Schröder, A. Préat, P. Lapointe, C. Blanpied

887

888

889

890

891

892

893

894

895

896

897

898

899

900

901

902

903

904

905

906

907

908

909

910

911

Evolution: a focus on southwestern Gondwana. Developments in Precambrian Geology, volume 16, Elsevier, 369-388.

Kennedy, M.J., Christie-Blick, N., Sohl and L.E., 2001. Are Proterozoic cap carbonates and isotopic excursions a record of gas hydrate destabilization following Earth's coldest intervals? Geology, 29, 443-446.

Kinsman, D.J.J., 1969. Modes of formation, sedimentary associations and diagnostic features of shallow-water and supratidal evaporates. American Association of Petroleum Geologists Bulletin, 53, 830-840.

Kirschvink, J.L., 1992. Late Proterozoic Low-Latitude Global Glaciation: the Snowball Earth. In: J.W. Schopf and C. Klein (Editors), The Proterozoic Biosphere: a Multidisciplinary study. Cambridge University Press, Cambridge, United Kingdøm, 51-52.

Konopásek, J., Kosler, J., Sláma, J. and Janousek, V., 2014. Timing and sources of precollisional Neoproterozoic sedimentation alongthe SW margin of the Congo Craton (Kaoko Belt, NW Namibia). Gondwana Research, 26, 386-401.

Lehmann, J., Saalmann, K., Naydenov, K.V., Milani, L., Belyanin, G.A., Zwingmann, H., Charlesworth, G. and Kinnaird, J.A., 2016. Structural and geochronological constraints on the Pan-African tectonic evolution of the northern Damara Belt, Namibia. Tectonics, 35 (1), $103-135$.

Lepersonne, X., 1951. Données nouvelles sur la stratigraphie des territoires anciens du BasCongo. Bulletin belge de Géologie, Paléontologie, Hydrologie, LX-2, 169-189.

Lepersonne, J., 1973. Carte géologique à l'échelle 1/200000. Notice explicative de la feuille Ngungu (Degré carré S6/14 = SB 33.9). République Démocratique du Congo. Département des Mines, Direction du Service Géologique. 61pp

Li, Z.X., Bogdanova, S.V., Collins, A.S., Davidson, A., DeWaele, B., Ernst, R.E., Fitsimons, I.C.W., Fuck, R.A., Gladkochub, D.P., Jacobs, J., Karlstom, K.E., Lu, S., Natapov, L.M., 
F. Delpomdor, S. Schröder, A. Préat, P. Lapointe, C. Blanpied

912 Pease, V., Pisarevsky, S.A., Thrane, K. and Vernikovsky, V., 2008. Assembly,

913 configuration, and break-up history of Rodinia: a synthesis. Precambrian Research, 160 (1-

914 2), 179-210.

915 Martin, H., 1965. The Precambrian geology of South West Africa and Namaqualand.

916 Precambrian Research Unit, volume 24, University of Cape Town, Cape Town, South

$917 \quad$ Africa. 159pp

918 Martins-Neto, M.A., Pedrosa-Soares, M.A. and Lima, S.A.A., 2001. Tectono-sedimentary

919 evolution of sedimentary basins from late Paleoproterozoic to late Neoproterozoic in the

920 São Francisco craton and Araçuaí Fold Belt, eastern Brazil. Sedimentary Geology, 141-142, $921 \quad 343-370$.

922 McGee, B., Halverson, G.P. and Collins, A.S., 2012. Cryogenian rift-related magmatism and 923 sedimentation: South-western Congo Craton, Namíbia. Journal of African Earth Sciences, $92476,34-49$.

925 Meert, J.G., 2003. A synopsis of events related to the assembly of eastern Gondwana.

926 Tectonophysics, 362, 1-40.

927 Merdith, A.S, Collins, A.S., Williams, S.E., Pisaversky, S., Foden, J.D., Archibald, D.B., 928 Blades, M.L., Alessio, B.L., Armistead, S., Plavsa, D., Clark, C. and Müller, R.D. 2017. A 929 full-plate global reconstruction of the Neoproterozoic. Gondwana Research, 50, 84-134.

930 Milani, L., Kimnaird, J.A., Lehmann, J., Naydenv, K.V., Saalmann, K., Frei, D. and Gerdes, 931 A., 2014. Role of crustal onribution in the early stage of the Damara Orogen, Namibia: new 932 constraints from combined $\mathrm{U}-\mathrm{Pb}$ and $\mathrm{Lu}-\mathrm{Hf}$ isotopes from the Goas Magmatic Complex. 933 Gondwana Research, 28, 961-986.

934 Miller, R.M., 2008. The Geology of Namibia, volume 3. Geological Survey of Namibia, 935 Windhoek, Namibia. 
F. Delpomdor, S. Schröder, A. Préat, P. Lapointe, C. Blanpied

936 Miller, R.M., 2013. Comparative stratigraphic and geochronological evolution of the

937 Northern Damara Supergroup in Namibia and the Katanga Supergroup in the Lufilian Arc

938 of Central Africa. Geoscience Canada, 40 (2), 118-140.

939 Monié, P., Bosch, D., Bruguier, O., Vauchez, Y., Nsungani, P. and Neto, A.B., 2012. The

940 Late Neoproterozoic/Early Palaeozoic evolution of the West Congo Belt of NW Angola:

941 geochronological (U-Pb and Ar-Ar) and petrostructural constraints. Terra Nova, 24, $238-$

942247.

943 Nagel, R., 1999. Eine Milliarde Jahre geologischer Entwicklung am NW-Rand des Kalahari

944 Cratons. Unpublished PhD thesis, University of Göttingen, Göttingen, Germany. 169pp

945 Nascimento, D.B., Ribeiro, A., Trouw, R.A.J., Schmitt, R.S. and Passchier, C.W., 2016.

946 Stratigraphy of the Neoproterozoic Damara Sequence in northwest Namibia: Slope to basin

947 sub-marine mass-transport deposits and olistolith fields. Precambrian Research, 278, 108-

$948 \quad 125$.

949 Naydenov, K.V., Lehmann, J., Saalmann, K., Milani, L., Kinnaird, J.A., Charlesworth, G.,

950 Frei, D. and Rankin,W., 2014. New constraints on the Pan-African Orogeny in Central

951 Zambia: a structural and geochronological study of the Hook Batholith and the Mwembeshi

952 Zone. Tectonophysics, 637,80-105.

953 Paula-Santos, G.M., Babinski, M., Kuchenbecker, M., Caetano-Filho, S., Trindade, R.I. and

954 Pedrosa-Soares, A.C. 2015. New evidence of an Ediacaran age for the Bambuí Group in

955 southern São Francisco craton (eastern Brazil) from zircon U-Pb data and isotope

956 chemostratigraphy. Gondwana Research, 28 (2), 702-720.

957 Paula-Santos, G.M., Caetano-Filho, S., Babinski, M., Trindade, R.I.F. and Guacaneme, C., 958 2017. Tracking connection and restriction of West Gondwana São Francisco Basin through 959 isotope chemostratigraphy. Gondwana Research, 42, 280-305. 
F. Delpomdor, S. Schröder, A. Préat, P. Lapointe, C. Blanpied

960 Pedrosa-Soares, A.C. and Alkmin, 2011. How many rifting events preceded the development 961 of the Araçuai-West Congo orogen? Geonomos, 19 (2), 244-251.

962 Pedrosa-Soares, A.C., Noce, C.M., Wiedemann, C.M. and Pinto, C.P., 2001. The Araçua1-

963 West- Congo Orogen in Brazil: an overview of a confined orogen formed during

964 Gondwanaland assembly. Precambrian Research, 110 (1), 307-323.

965 Pedrosa-Soares, A.C., Alkmin, F., Tack, L., Noce, C., Babinski, M., Silva, L. and Martins966 Neto, M., 2008. Similarities and differences between the Brazilian and African counterparts

967 of the Neoproterozoic Araçuaí-West Congo Orogen. In: J. Pankhurst, R. Trouw, B. Brito-

968 Neves, and M. De Wit (Editors), West Gondwana: Pre-cenozoic Correlations Across the

969 South Atlantic Region 294. Geological Society of London, Special Publications, London, $970 \quad$ United Kingdom, 153-172.

971 Poidevin, J.-L., 2007. Stratigraphie isotopique du strontium et datation des formations

972 carbonatées et glaciogéniques néoprotérozoïques du Nord et de l'Ouest du craton du Congo.

973 Comptes Rendus Geoscience, 339, 259-273.

974 Porada, H., 1983. Die Geosynklinalentwieklung des Damara-Orogens in Namibia und ihr

975 geodynamischer Rahmen. Unpublished habilitation thesis, Universität von Göttingen,

976 Göttingen, Germany. 209pp

977 Porada, H., 1989. Pan-African rifting and orogenesis in southern to equatorial Africa and 978 eastern Brązil. Precambrian Research, 44, 103-136.

979 Porada, H. and Berhorst, V., 2000. Towards a new understanding of the Neoproterozoic-Early 980 Paleozoic Lufilian and northern Zambezi Belts in Zambia and DRC. Journal of African $981 \quad$ Earth Sciences, 30, 727-771.

982 Pratt, B.R., James, N.P. and Clinton, A.C., 1992. Peritidal carbonates. In: R.G. Walker and 983 N.P. James (Editors), Facies Models: Response to Sea Level Change. Geological 984 Association of Canada. 409pp 
F. Delpomdor, S. Schröder, A. Préat, P. Lapointe, C. Blanpied

985 Prave, A.R., Condon, D.J., Hoffmann, K.H., Tapster, S. and Fallick, A.E., 2016. Duration and 986 nature of the end-Cryogenian (Marinoan) glaciation. Geology, 44 (8), 631-634.

987 Préat, A., Prian, J.P., Thiéblemont, D., Mabicka Obame, R. and Delpomdor, F., 2011. Stable

988 isotopes of oxygen and carbon compositions in the Neoproterozoic of South Gabon

989 (Schisto-Calcaire Subgroup, Nyanga Basin): Are cap carbonates and lithoherms recording a

990 particular destabilization event after the Marinoan glaciation? Journal of African Earth

$991 \quad$ Sciences, $60(4), 273-287$.

992 Prian, J.P., Thiéblemont, D., Préat, A., Goujou, J.C., Simo Ndounze, S. and Ekogha, H., 2009.

993 Notice explicative de la Carte géologique de la République du Gabon à $1 / 200000$, feuille

994 Ndendé. Editions DGMG - Ministère des Mines, du Pétrole, des Hydrocarbures, Libreville.

995 Rainaud, C., Master, S., Armstrong, R.A., Phillips, D. and Robb, L.J., 2005. Monazite U-P

996 dating and ${ }^{40} \mathrm{Ar}-{ }^{39} \mathrm{Ar}$ thermochronology of metamorphic events in the Central African

997 Copperbelt during the Pan-African Lufilian Orogeny. Journal of African Earth Sciences, 42

$998 \quad(1), 183-199$.

999 Reis, H.L.S. and Alkmim, F.F., 2015. Anatomy of a basin-controlled foreland fold-thrust belt

1000 curve: the Três Marias salient, São Francisco basin, Brazil. Marine Petoleum Geology, 66

$1001 \quad(4), 711-731$.

1002 Reitlinger, E.A., 1959. Atlas des restes microscopiques et des Problemática des couches

1003 anciennes de Sibérie. Travaux de Géologie, Atlas Nauka Acad. Sci., URSS, 25, 1-63.

1004 Rodler, A.S., Frei, R., Gaucher, C., Korte, C., Rosing, S.A. and Germs, G.J.B., 2017.

1005 Multiproxy isotope constraints on ocean compositional changes across the late

1006 Neoproterozoic Ghaub glaciation, Otavi Group, Namibia. Precambrian Research, 298, 306-

1007324. 
F. Delpomdor, S. Schröder, A. Préat, P. Lapointe, C. Blanpied

1008 Santos, R.V., S. de Alvarenga, C.J., Dardenne, M.A., Sial, A.N. and Ferreira, V.P., 2000.

1009 Carbon and oxygen isotope profiles across Meso-Neoproterozoic limestones from central

1010 Brazil: Bambuí and Paranoá groups. Precambrian Research, 104, 107-122.

1011 Scoffin, T.P. and Stoddard, D.R., 1983. Beachrock and intertidal cements. In: A.S. Goudie

1012 and K. Pye (Editors), Chemical sediments and geomorphology. Academic Press, London,

1013 United Kingdom, 401-425.

1014 Shearman, D.J., 1978. Evaporites of coastal sabkhas. Society and Economist Paleontolongists

1015 and Mineralogists Short Course, volume 4, 6-42.

1016 Stanistreet, I.G., Kukla, P.A. and Henry, G, 1991. Sedimentary basinal responses to a Late

1017 Precambrian Wilson Cycle: the Damara Orogen and Nama Foreland, Namibia. Journal of 1018 African Earth Sciences, 13 (1), 141-156.

1019 Straathof, G.B., 2011. Neoproterozoic Low Latitude Glaciations: An African Perspective.

1020 Unpublished PhD. Thesis, University of Edinburgh, Edinburgh, Scotland. 283pp

1021 Tack, L., Wingate, M.T.D., Liégeois, J.-P., Fernandez-Alonzo, M. and Deblond, A., 2001.

1022 Early Neoproterozoic magmatism(1000-910 Ma) of the Zadinian and Mayumbian groups

1023 (Bas-Congo), onset of Rodinia rifting at the western edge of the Congo Craton. Precambrian

$1024 \quad$ Research, 110, 277-306.

1025 Tait, J., Delpomdor, F., Préat, A., Tack, L., Straathof, G. and Kanda Nkula, V., 2011.

1026 Neoproterozoic sequences of the West Congo and Lindi/Ubangi Supergroups in the Congo

1027 Craton, Central Africa. In: E. Arnaud, G.L. Halverson and G. Shields-Zhou (Editors), The

1028 Geological Record of Neoproterozoic Glaciations. Geological Society Memoir, volume 36,

1029 London, United Kingdom, 185-194.

1030 Thomson, D., Rainbird, R.H. and Dix, G., 2014. Architecture of a Neoproterozoic

1031 intracratonic carbonate ramp succession: Wynniatt Formation, Amundsen Basin, Arctic

1032 Canada. Sedimentary Geology, 299, 119-138. 
F. Delpomdor, S. Schröder, A. Préat, P. Lapointe, C. Blanpied

1033 Turner, E.C., James, N.P. and Narbonne, G.M., 2000. Taphonomic Control on Microstructure

1034 in Early Neoproterozoic Reefal Stromatolites and Thrombolites. Palaios, 15 (2), 87-111.

1035 Uhlein, G.J., Carvalho, J.F.M.G., Uhlein, A., Caxito, F.A., Halverson, G.P. and Sial, A.N.,

1036 2013. Estratigrafia e sedimentologia da Formação Carrancas, Grupo Bambuí, nas regiões de

1037 Belo Horizonte e Pitangui - MG. Geonomos, 20(2), 79-97.

1038 Uhlein, G.J., Uhlein, A., Halverson, G.P., Stevenson, R., Caxito, F.A., Cox, G.M. and de

1039 Carvalho, J.F.M.G., 2016. The Carrancas Formation, Bambuí Group: A record of pre-

1040 Marinoan sedimentation on the southern São Francisco craton, Brazil. Journal of South

1041 American Earth Sciences, 71, 1-16.

1042 Unrug, R., 1995. Rodinia and Gondwana: A record of supercontinent configuration change.

1043 In: M. Yoshida and M. Santosh (Editors), India and Antarctica during the Precambrian.

1044 Geological Society of India Memoir, volume 34, 1-9.

1045 Van Smeerdijk Hook, A. and Wallace, M.W., 2018. Neoproterozoic marine carbonates and

1046 their paleoceanographic significance. Global and Planetary Change 160, 28-45.

1047 Wachter, E. and Hayes, J.M., 1985. Exchange of oxygen isotopes in carbon-dioxide

1048 phosphoric acid systems. Chemical Geology 52, 365-374.

1049 Warren, L.V., Quaglio, F., Riecomini, C., Simoes, M.G., Poiré, D.G., Strikis, N.M., Anelli, A.

1050 and Strikis, P.C. 2014. The puzzle assembled: Ediacaran guide fossil Claudina reveals an

1051 old proto-Gondwana seaway. Geology, 42 (5), 391-394.

1052 Yakschin, M.S. and Luchinina, V.A., 1981. New materials of fossil alga Family

1053 Oscillatoriaceae (KIRCHN.) Elenkin. In Boundary strata between the Precambrian and

1054 Cambrian in Siberian Platform. Novosibirsk, Scienca, 28-34.

1055

1056 Editorial Handling: S. McCourt

1057 
F. Delpomdor, S. Schröder, A. Préat, P. Lapointe, C. Blanpied

1058 Table

1059

1060 Table 1: Summary of lithofacies association characteristics of the Hüttenberg Formation

1061 (Namibia) and the C5 Formation (Democratic Republic of Congo)

1062

1063

Table 2: C-, O- and Sr-isotopic and elemental geochemical data.

1064

1065

1066

1067

1068

1069

1070

1071

1072

1073

1074

1075

1076

1077

1078

1079

1080

1081

1082 
F. Delpomdor, S. Schröder, A. Préat, P. Lapointe, C. Blanpied

\section{Figures}

1084

1085 Figure 1: Cartoon illustrating the Neoproterozoic palaeogeographic reconstruction of the

1086 Congo-São Francisco (C-SF) cratons (modified after Stanistreet et al. 1991; Alkmim et al.

1087 2006). (A) Reworked 1.1 Ga-950 Ma Rodinia Supercontinent centered on the present-day

1088 Africa and South America continents. (B) Continental rifting at $\sim 1$ Ga. (C) Opening of the

1089 Khomas Ocean separating shelves on the C-SF and Kalahari continental margins. (D) Initial

1090 closure of the Adamastor Ocean, at 720 Ma, as a consequence of the C-SF, Rio de la Plata,

1091 Kalahari interaction. (E) Pan-African-Brasiliano orogen on the Gondwana Supercontinent at

1092 540 Ma. Abbreviations: Craton-Am, Amazonia; RP, Rio de la Plata, WA, West Africa; Co,

1093 Congo; SF, São-Francisco; Ka, Kalahari, Ta, Tanzania block (Congo craton); AR, Arequipa;

1094 Ho, Hoggar; In, India; EAn, East Antarctica; Was, West Australia; NAs, North Australia; Ga,

1095 Gawler. Pan-African-Brasiliano orogens - RP, Rio Preto, BR, Brasiliano; SP, Sierra

1096 Pampeanas; WC, West Congo; KK, Kaoko, DA, Damara; GA, Gariep; LF, Lufilian; ZB,

1097 Zambezi; MO, Mozambique; SA, Saldania; CF, Cape Fold; RO, Ross; KA, Kanmatoo. Stars:

1098 C5 Formation in the Democratic Republic of Congo, Hüttenberg Formation in Namibia.

1099

1100 Figure 2: (A) Regional geological sketch map of the study area. (B) Geological map of the

1101 section Lukala-Mbanza Ngungu (after Cailteux et al., 2015). (C) Geological map of the

1102 Damara belt (after Kamona and Günzel, 2007). Location of the studied outcrops and core

1103 sections in yellow stars.

1104

1105 Figure 3: Lithostratigraphy and chronostratigraphy of the (A) Damara Supergroup and (B)

1106 the West Congo Supergroup (see text for discussion). New and previous terminology of the 
F. Delpomdor, S. Schröder, A. Préat, P. Lapointe, C. Blanpied

1107 West Congo Supergroup falls outside the scope of this paper but is briefly discussed in Kant-

1108 Kabalu et al. (2016).

1109

1110 Figure 4: Detailed lithostratigraphy coupled with microfacies analyses. (A) Tsumeb Mine

1111 (GPS coordinate: S19¹4’07.80/E17²3'49.40). (B) Tsumeb town (GPS coordinate: $S$

$\left.1112 \quad 19^{\circ} 15^{\prime} 60.60 / E 17^{\circ} 42^{\prime} 44.30\right)$. (C) S\#66 drillcore (GPS coordinate: N304893/E76412).

1113

1114 Figure 5: Detailed lithostratigraphy coupled with microfacies analyses. (A) MJNM\#5

1115 drillcore, farm Vogelsang 284 (GPS coordinate: S19¹0’00.86/E18²1 42.01). (B) MJNM\#6

1116 drillcore, farm Guinab 277 (GPS coordinate: S19¹1'11.57/E18022 48.53). (C) MJNM\#9

1117 drillcore, farm Guinab 277 (GPS coordinate: S19¹0’10.46/E18922’47.86) (D) MJNM\#10

1118 drillcore, farm Vogelsang 284 (GPS coordinate: S9॰12'51.38/E1757'28.12). (E) MJNM\#12

1119 drillcore, Farm Bombay 670 (GPS coordinate: S19912'51.38/E1757’28.12).

1120

1121 Figure 6: Detailed lithostratigraphy and hithology coupled with microfacies analyses and C

1122 isotopes. (A) GX6c drillcore (RMCA serial number RG40421-40466). (B) GN7/9a drillcore

1123 (RMCA serial number RG40178-40198).

1124

1125 Figure 7: Vertical changes of microfacies (MF1 to MF12) represented by type-1 and -2

1126 cycles of open marine- to restricting-upward carbonate sequences. The type-1 cycle is

1127 characterized by a LFA-H1 to LFA-H4 succession of complete cycles that begin with LFA-

1128 H1, while the type-2 cycle contains a LFA-C1 to LFA-C5 succession that begin with LFA-C1

1129 (see text for discussion).

1130 
F. Delpomdor, S. Schröder, A. Préat, P. Lapointe, C. Blanpied

1131 Figure 8: Carbonate ramp geometry and facies distribution of the Hüttenberg Formation in

1132 Namibia and the C5 Formation in DRC. (A-C) Middle- to inner carbonate ramp of the

1133 Hüttenberg Formation. (A) Middle carbonate ramp of the Hüttenberg Formation with

1134 (dolo)mudstone (MF1-2) overlain by mounds and pinnacles of microbial and SH/LLH-type

1135 stromatolitic buildups (MF3-5). High-energy oolitic (dolo)packstone-grainstone (MF6) form

1136 barrier shoals. (B) Inner carbonate ramp of the Hüttenberg Formation exhibits a temporary

1137 emerged hypersaline lagoon with desication cracks and breccias (see MF10). (C-D) Inner

1138 carbonate-evaporite ramp of the C5 Formation. (C) Shoal-barrier and lagoonal ramp

1139 settings of the C5a Member (MF7-9). (D) Nearshore carbonate-evaporite ramp setting with

1140 beach and coastal sabkha plain (MF10-12).

1142 Figure 9: Attempt at carbon-isotope correlation between the C5 carbonate rocks and the

1143 high-resolution $\delta^{13} \mathrm{C}$ data from the Tsumeb core $\$ 86$ A drilled in the Hüttenberg Formation

1144 (data after Kaufman et al. 2010).

1146 Figure 10: Composite carbon-isotope profiles and simplified stratigraphic columns spanning

1147 the inferred Marinoan and Pan-African deformation events in northwestern Namibia, west

1148 central DRC, and centrat east Brazil. The three sedimentary successions are marked by two

1149 marine transgressions, after the Marinoan-age glaciation. Two carbon-isotope trends show

1150 (i) avery negative anomaly, directly after the Marinoan glaciation, marked by the deposition

1151 of the Ghaub Formation in Namibia, Upper Diamictite Formation in DRC, and

1152 Carrancas/Jequitai formations in Brazil, (ii) a negative to positive excursion in $\delta^{13} C$ values in

1153 the Maieberg Formation in Namibia, comparable to the C1-C3 formations in DRC, and the

1154 lower part of the Sete Lagoas in Brazil, and (iii) a second negative to strong positive

1155 excursion in $\delta^{13} C$ values in the Elandshoek-Huttenberg formations in Namibia, comparable to 
F. Delpomdor, S. Schröder, A. Préat, P. Lapointe, C. Blanpied

1156 the C4-C5 formations in DRC, and the upper part of the Sete Lagoas Formation to the Lagoa

1157 do Jacaré Formation in Brazil. The ${ }^{87} \mathrm{Sr}{ }^{86} \mathrm{Sr}$ ratios are here indicative ${ }^{87} \mathrm{Sr}{ }^{86} \mathrm{Sr}$ ratios from-

1158 Namibia: Frimmel et al. (1996) and Halverson et al. (2007); DRC: Frimmel et al. (2006),

1159 Poidevin (2007), and Delpomdor and Préat (2013); Brazil: Caxito et al. (2012) and Paula-

1160 Santos et al. $(2015,2017)$.

1161

1162 Plate

1163

1164 Plate 1: Microfacies analysis. (A) Homogeneous mudstone (MF1). (B) Planar to wispy

1165 parallel laminated mudstone (MF2). (C) Tighly-packed microbial tubular filaments in a

1166 bindstone texture (MF3). (D) Silt-to sand-sized peloidal wackestone/grainstone (MF4). (E)

1167 stromatolitic boundstone with fenestral fabric filled by equant calcite cements (MF5). (F)

1168 Tightly packed fine-grained concentric tangentialto radial oolites in a packstone texture

1169 (MF6). (G) Reworked stromatoclasts in an oolitic grainstone cemented by calcite cements

1170 (MF6). (H) Thin-levels of oolitic and peloidal packstone (MF6) alternating with

1171 homogeneous mudstone (MF7). (I) Vertical desiccation crack in a homogeneous mudstone

1172 (MF7) capped by thin wavy parallel laminated mudstone (MF8). (J) Thin planar to oblique

1173 parallel microbial laminations. (K) Oolitic grainstone (MF9) in calcite cements. (L)

1174 Occurrence of helicoidal cyanobacteria, attributed to Obruchevella parva Reitlinger (1959),

1175 in the nucleus of oolites ('Kisantu Oolite', see Alvarez et al. 1995). (M) Alternations of planar

1176 to wayy parallel microbial laminites (MF10) and evaporitic mudstone (MF11). (N) Small-

1177 sized nodules showing loosely packed aggregates of tiny platy rectangular laths and stellate

1178 crystals (MF11). (O) Dolomitized lime mudstone (MF12) capped by evaporitic mudstone

1179 (MF11). 


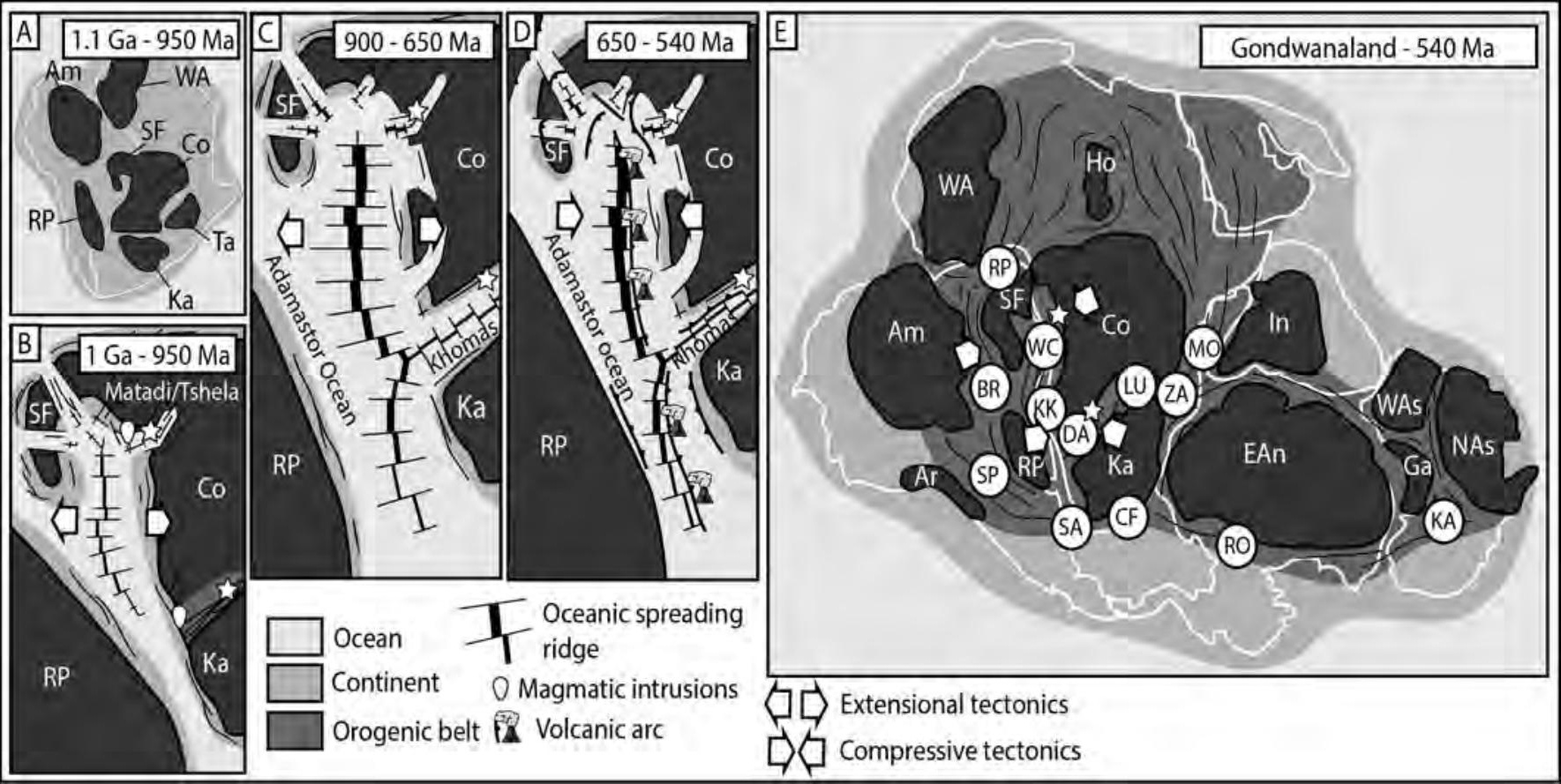




\section{STRATIGRAPHY: DAMARA SUPERGROUP (NAMIBIA)}

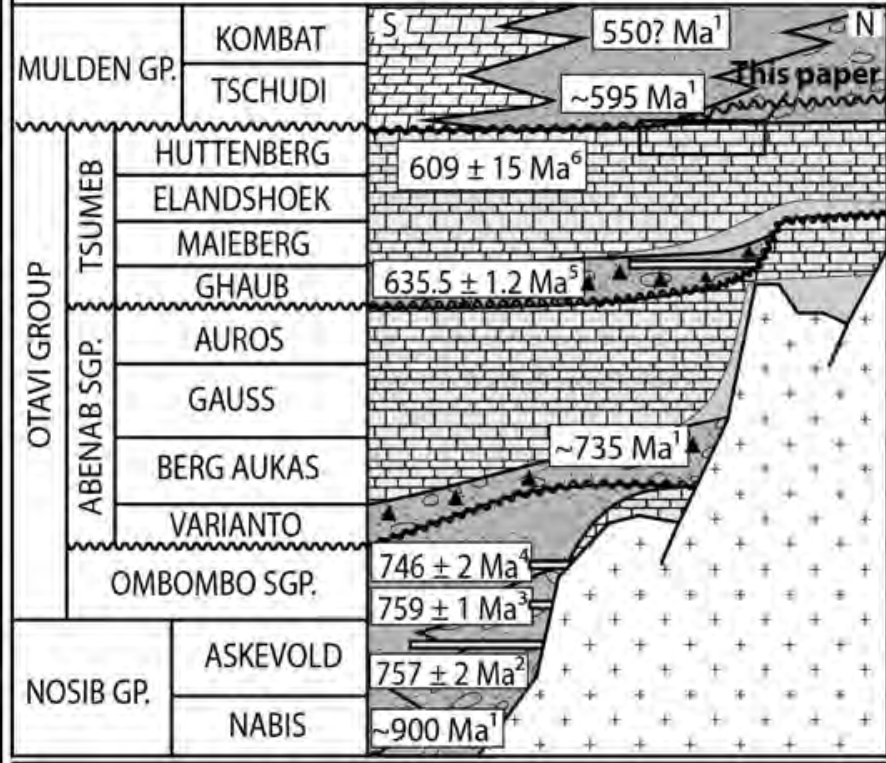

\section{LEGEND}

$+\rightarrow$ BASEMENT

$\checkmark v$ MAGMATIC AND VOLCANIC ROCKS

[5] METACONGLOMERATE

D GNEISS, QUARTZITE

SCHIST, PHYLLADE ECONGLOMERATE
STRATIGRAPHY: WEST CONGO SUPERGROUP (DRC)

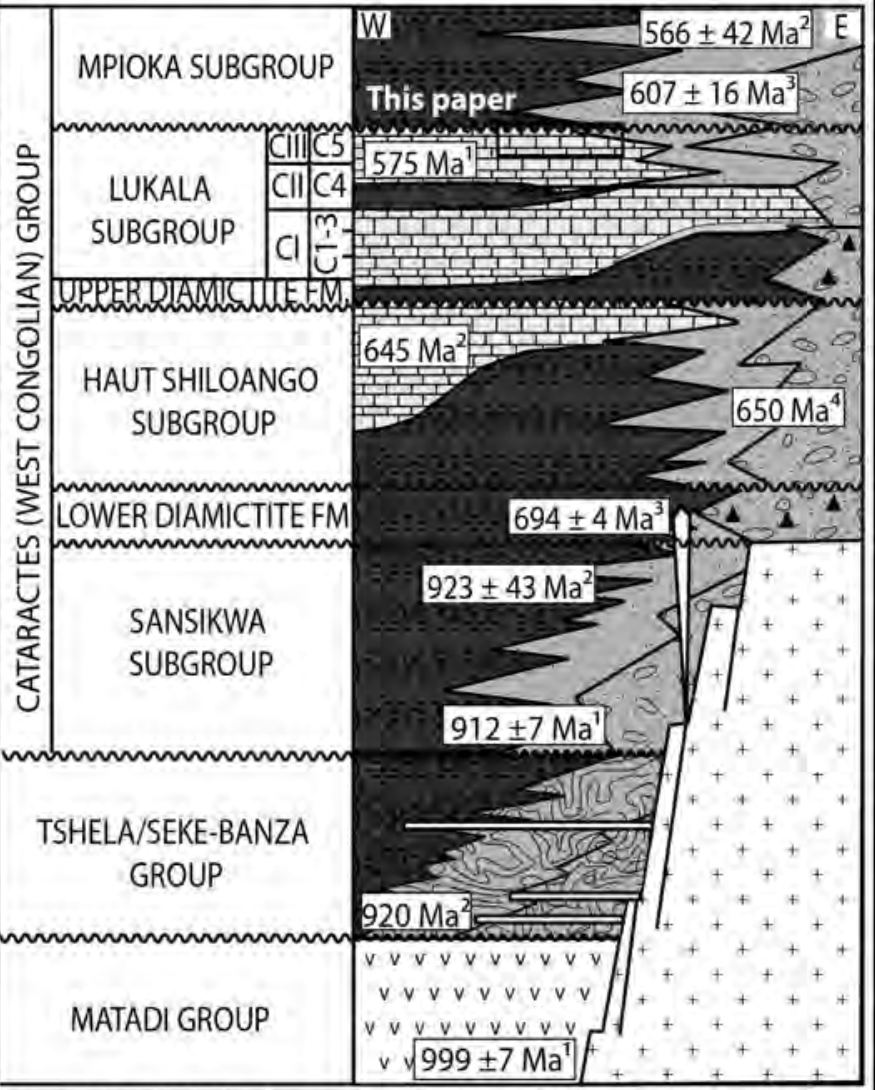

GEOCHRONOLOGY: NAMIBIA: ${ }^{1}$ Kamona and Günzel (2007), ${ }^{2} \mathrm{Hoffmann}$ et al. (1994), ${ }^{3} \mathrm{Halverson}$ et al. (2005), ${ }^{4} \mathrm{Hoffman}$ et al. (1996), ${ }^{5}$ Hoffmann et al. (2004), ${ }^{6} \mathrm{Nagel}$ (1999). DRC: 'Tack et al. (2001), ${ }^{2}$ Frimmel et al. (2006), ${ }^{3}$ Straathof (2011), ${ }^{4}$ Poidevin (2007) 


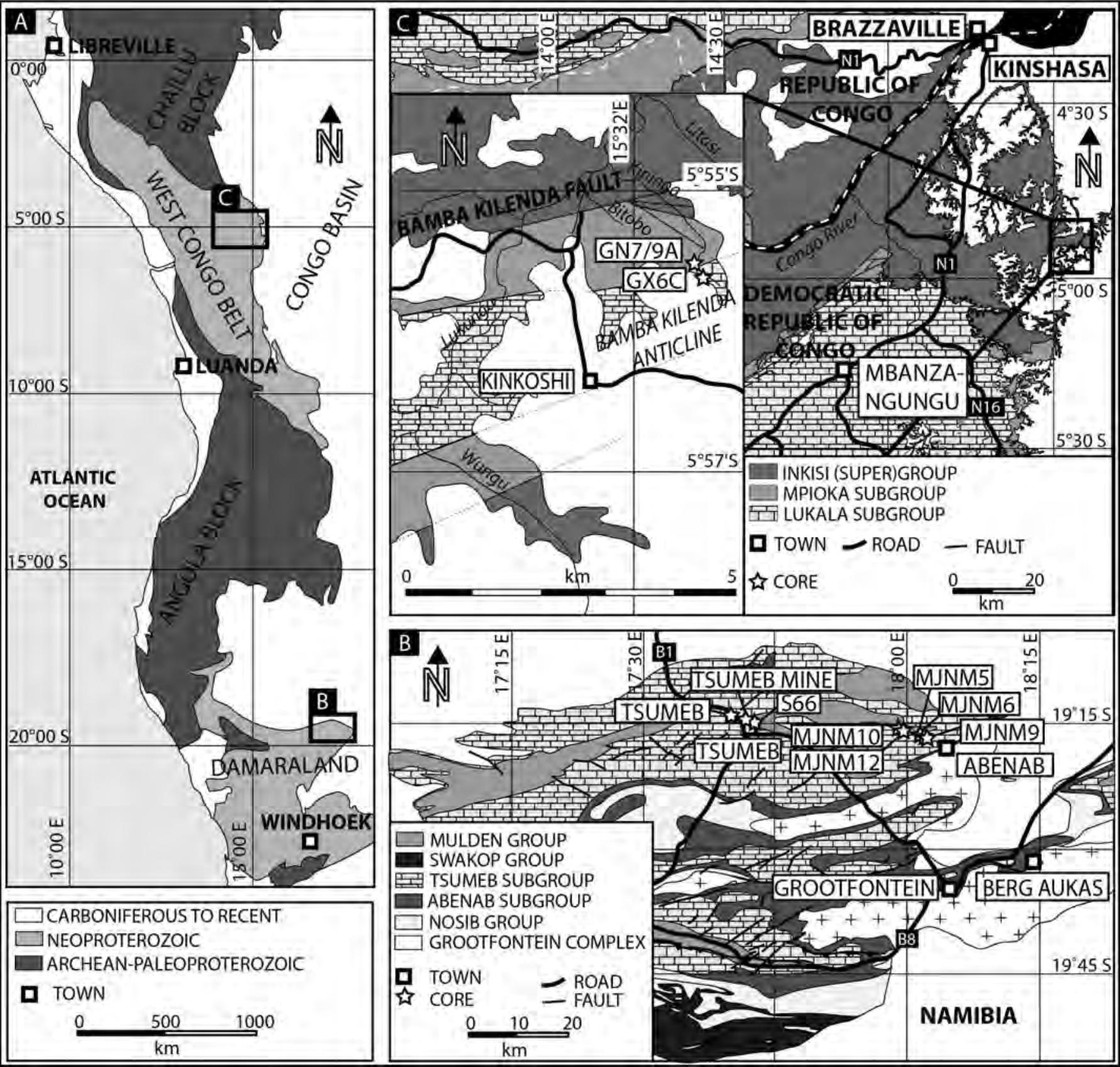




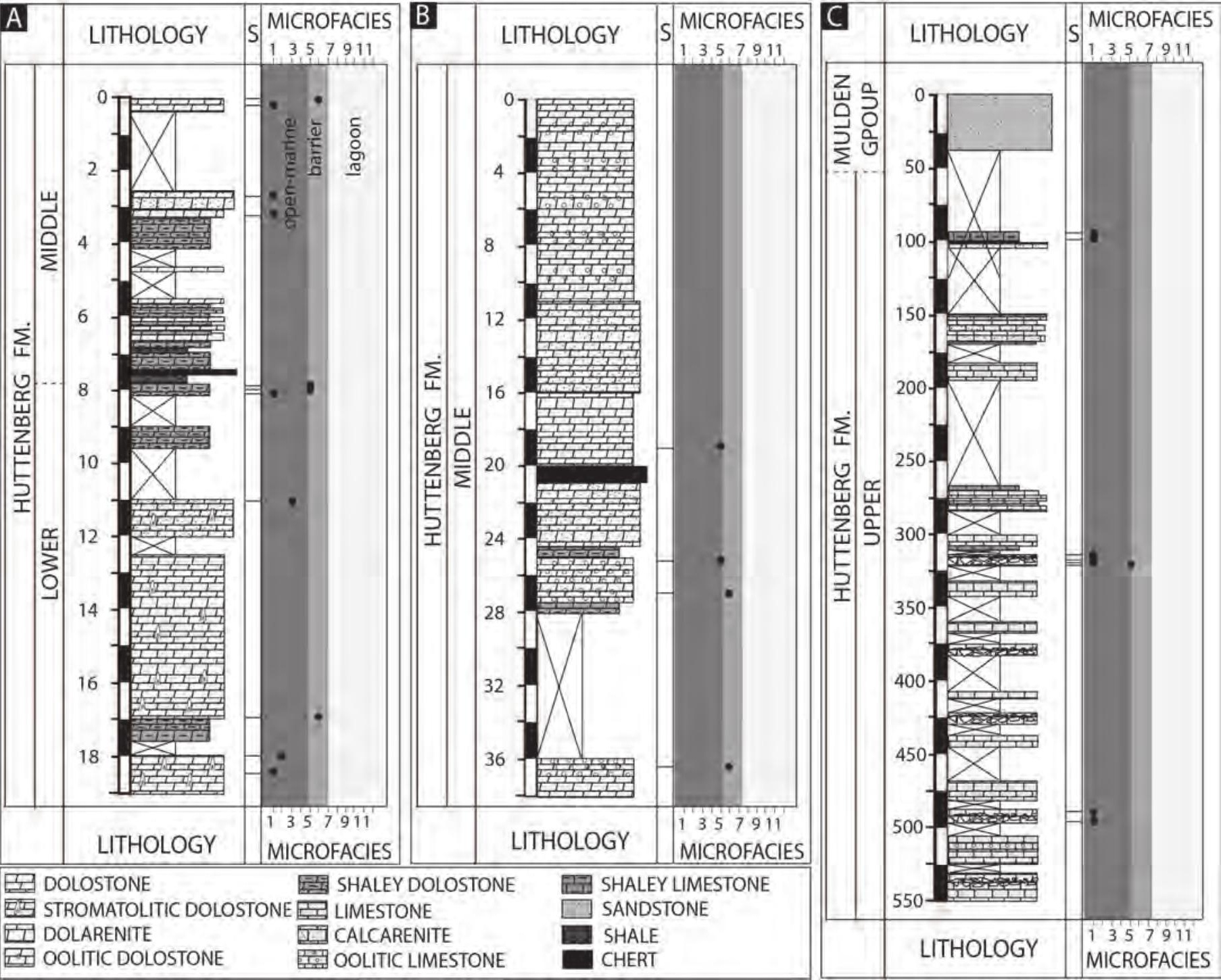




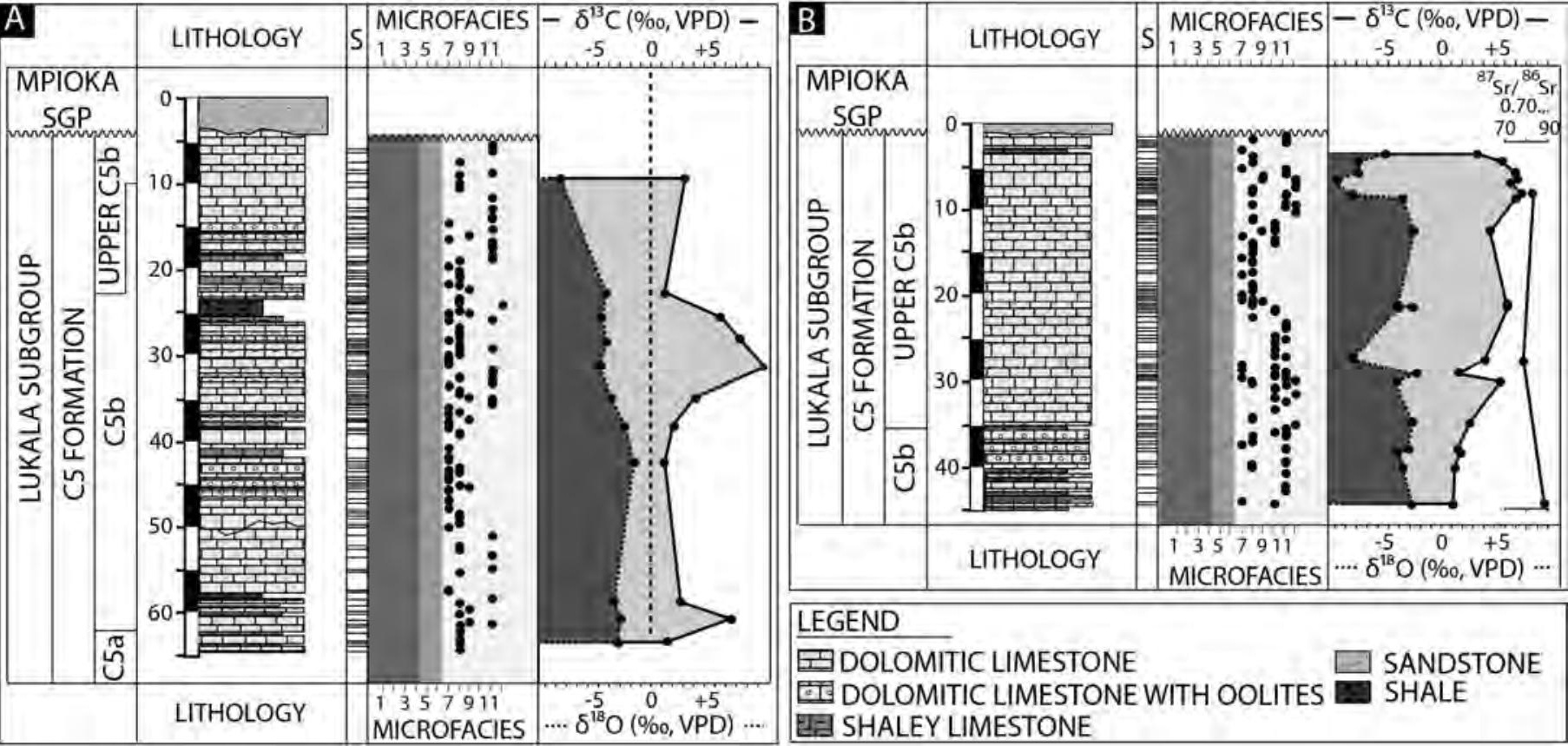




\section{Type-1 cycle - open marine}

\section{Environment}

\section{Lithofacies association}

Intertidal

shoal barrier

Sub- to intertidal organic mounds and pinnacles

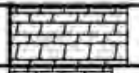

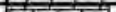

Oolitic (dolo)packstone/ grainstone (MF6)

LFA-H4

Stromatolitic

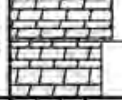

(dolo)boundstone (MF5)

Peloidal (dolo)wackestone/ packstone (MF4)

\section{Microbial}

(dolo)bindstone (MF3)

Shallow subtidal

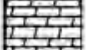
open-marine

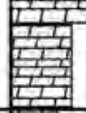

Laminated
(dolo) mudstone (MF2)

$\mathrm{LFA}-\mathrm{HZ}$ LFA-H3

Argillaceous
o)mudstone (MF1)

Subtidal

open-marine 㱬

LFA-H1

\section{Type-2 cycle - lagoon to nearshore}

Environment

\section{Lithofacies association}

\section{Soil}

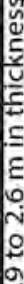

Supratidal sabhka

inter-to supratidal mudflat

Intertidal beach

sub- to intertidal lagoon
Calcrete (MF12)

Evaporitic dolomudstone (MF11) LFA-C4 Microbially laminated mudstone (MF10)

Oolitic grainstone (MF9)

LFA-C3

LFA-CS

$L F A-C 2$

돈

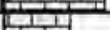

Laminated mudstone (MF8) 
A Hüttenberg Formation: lower-middle member

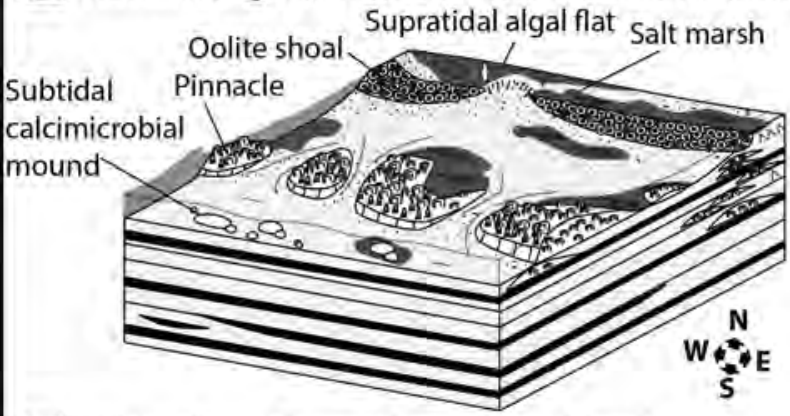

B] Hüttenberg Formation: upper Member

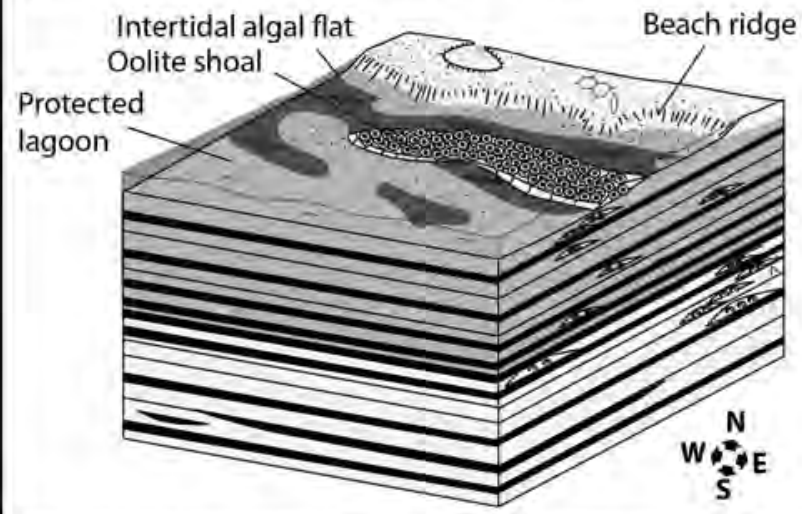

Hüttenberg Formation: lower-upper members

$\square$ Dolomitic limestone with oolites (upper member)

$\square$ Dolomitic limestone with stromatolites and oolites (lowermiddle member) -Dolomitic shale
[0.6) Olitic grainstone

¿ Cyanobacterial bindstone

Encrusted dolomitic limestone

$\exists$ Calcarenite
C. C5 Formation: C5a member

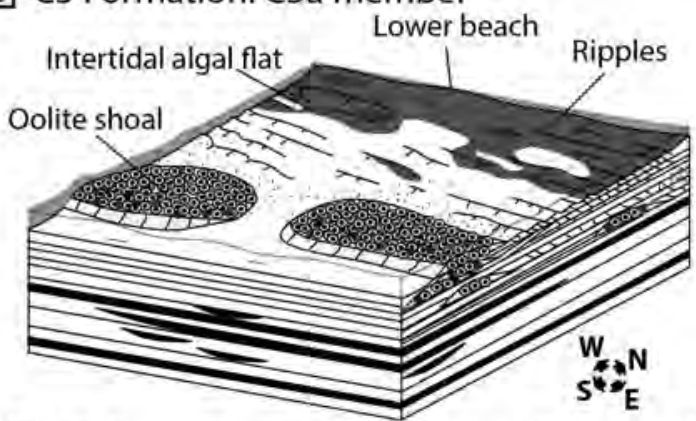

D C5 Formation: C5b and upper C5b members

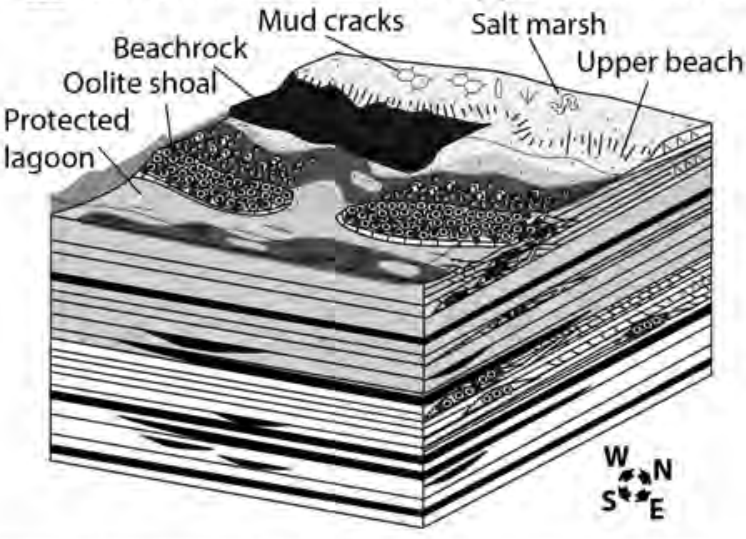

C5 Formation: C5a-upper C5b members

$\square$ Calcareous and dolomitic shale ( $\mathrm{C} 5 \mathrm{a}$ )

$\square$ Dolomitic limestone with stromatolites and oolites (C5b-upper C5b) - Dolomitic shale

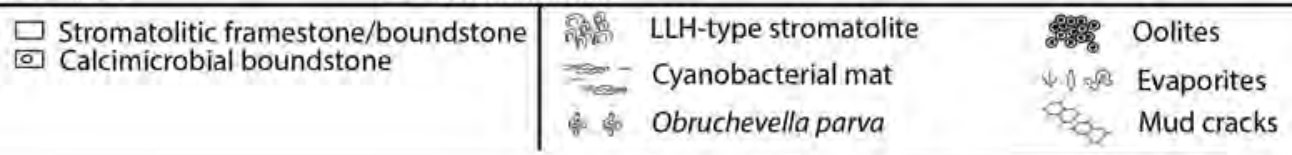


THIS PAPER

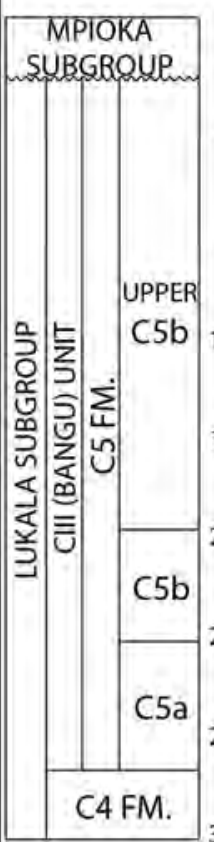

$\delta^{13} C(\% \circ, \mathrm{VPD}) \quad \delta^{13} C(\%, \mathrm{VPD})$

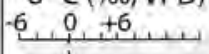

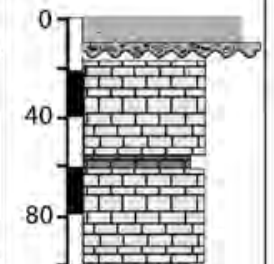

TSUMEB CORE S86A

(AFTER KAUFMAN ET AL., 2010)

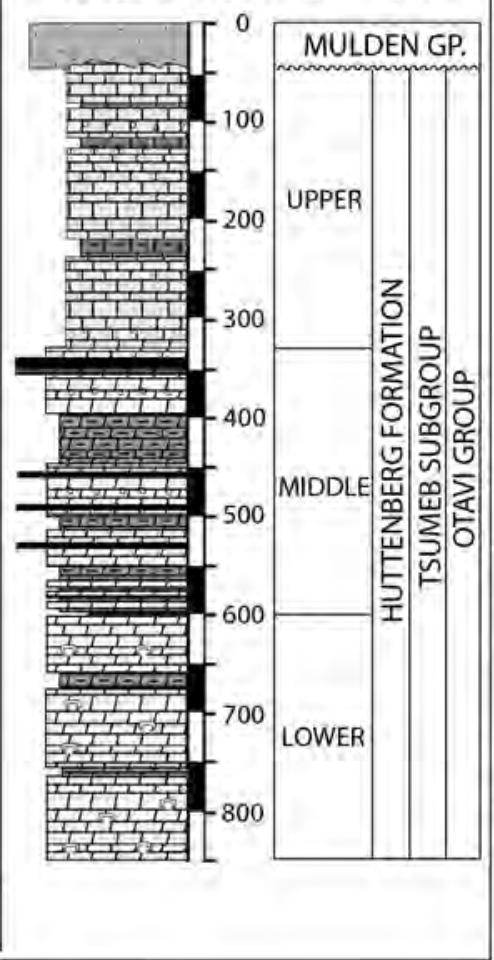

垔 DOLOSTONE

STROMATOLITICDOLOSTONE TII OOLITIC DOLOSTONE

몰 SHALEY DOLOSTONE

回 DOLOMITIC LIMESTONE

OOLITICLIMESTONE

[1ㅁㅁ SHALEY LIMESTONE

SANDSTONE

SHALE

CHERT 


\begin{tabular}{|c|c|c|c|}
\hline $\begin{array}{l}\text { Lithofacies } \\
\text { associations }\end{array}$ & Microfacies & General descriptions & $\begin{array}{l}\text { Depositional } \\
\text { environment }\end{array}$ \\
\hline \multicolumn{4}{|c|}{ Hüttenberg Formation (Namibia) } \\
\hline LFA-H1 & MF1 & $\begin{array}{l}\text { Dark blue-grey microcrystalline massive argillaceous mudstone; locally } \\
\text { dolomitization; detrital grains; stylolites }\end{array}$ & $\begin{array}{l}\text { Subtidal open- } \\
\text { marine }\end{array}$ \\
\hline \multirow[b]{2}{*}{ LFA-H2 } & MF2 & $\begin{array}{l}\text { Light to dark blue-grey, planar to wispy parallel, thin- to non-laminated mudstone; } \\
\text { microcrystalline micrite, locallly dolomitization; detrital grains; rare replaced } \\
\text { gypsum and anhydrite crystals }\end{array}$ & \multirow{2}{*}{$\begin{array}{l}\text { Shallow subtidal } \\
\text { open-marine }\end{array}$} \\
\hline & MF3 & $\begin{array}{l}\text { Thin planar to wavy parallel bindstone, brownish to bluish-grey, closely-packed } \\
\text { tubular filaments and clumps of fragments of micro-organisms; microcrystalline } \\
\text { micrite, locallly dolomitization; detrital grains; rare replaced gypsum and anhydrite } \\
\text { crystals }\end{array}$ & \\
\hline \multirow[b]{2}{*}{ LFA-H3 } & MF4 & $\begin{array}{l}\text { Light blue-grey, fine- to medium-grained, moderately-sorted, peloidal wackestone- } \\
\text { packstone; microcrystalline micritic matrix, locally dolomitization }\end{array}$ & \multirow{2}{*}{$\begin{array}{l}\text { Sub- to intertidal } \\
\text { organic mound } \\
\text { and pinnacle }\end{array}$} \\
\hline & MF5 & $\begin{array}{l}\text { Light blue-grey, stromatolitic boundstonestromatolitic mats and clumps of } \\
\text { fragments of micro-organisms; SH- to LLH-type Conophyton; microcrystalline } \\
\text { micritic matrix, locally dolomitization; fenestrae; locally mudcracks }\end{array}$ & \\
\hline LFA-H4 & MF6 & $\begin{array}{l}\text { Light blue-grey, medium- to well-sorted, oolitic packstone-grainstone; planar or } \\
\text { trough cross laminations; peloids; locally dolomitization; interparticular calcite } \\
\text { cements; mudcracks }\end{array}$ & $\begin{array}{l}\text { Intertidal shoal } \\
\text { barrier }\end{array}$ \\
\hline \multicolumn{4}{|c|}{ C5 Formation (Democratic Republic of Congo) } \\
\hline \multirow{2}{*}{ LFA-C1 } & MF7 & $\begin{array}{c}\text { Thn-bedded dark-grey, locally pale pinkish argillaceous mudstone; microcrystalline } \\
\text { micrite, locally dolomitization; argillaceous seams and stylolites; abundant } \\
\text { replaced gypsum and anhydrite crystals }\end{array}$ & \multirow{2}{*}{$\begin{array}{l}\text { Sub- to intertidal } \\
\text { lagoon }\end{array}$} \\
\hline & MF8 & $\begin{array}{l}\text { Dark grey planar to wavy parallel, thin laminated mudstone; oblique and cross- } \\
\text { laminations; microcrystalline micrite, locally dolomitization; abundant replaced } \\
\text { gypsum and anhydrite crystals }\end{array}$ & \\
\hline LFA-C2 & MF9 & $\begin{array}{c}\text { Coarse grained, well-sorted, tighly-packed oolitic grainstone; planar or low angle } \\
\text { crossed laminations; locally dolomization or silicification; interparticular calcite } \\
\text { cements; mudcracks }\end{array}$ & Intertidal beach \\
\hline LFA-C3 & MF10 & $\begin{array}{l}\text { Thin microbially planar and wavy parallel laminated mudstone; microcrystalline } \\
\text { micrite, locally dolomitization; fenestrae; abundant replaced gypsum and } \\
\text { anhydrite crystals; mudcracks; pedogenic crusts }\end{array}$ & $\begin{array}{c}\text { Inter- to supratidal } \\
\text { mudflat }\end{array}$ \\
\hline LFA-C4 & MF11 & $\begin{array}{l}\text { Evaporitic dolomudstone; equigranular xeno- to hypidiotopic dolomitic matrix; } \\
\text { brownish to bluish white replaced gypsum crystals, nodular anhydrite and } \\
\text { interbeds of anhydrite, chicken-wire structure; mudcracks; hardgrounds }\end{array}$ & Supratidal sabhka \\
\hline LFA-C5 & MF12 & $\begin{array}{l}\text { Dark, rarely yellowish-orange, millimetric-thick crusts of slightly undulated } \\
\text { laminations; in-situ brecciation of dolomitized limestone; locally oolites and } \\
\text { peloids; abundant replaced gypsum and anhydrite crystals; mudcracks }\end{array}$ & Paleosoil \\
\hline
\end{tabular}




\begin{tabular}{|c|c|c|c|c|c|}
\hline Sample & Drillcore & Member & $\begin{array}{c}\delta^{13} \mathrm{C}(\%, \\
\text { VPDB) }\end{array}$ & $\begin{array}{c}\delta^{18} \mathrm{O}(\%, \\
\text { VPDB) }\end{array}$ & ${ }^{87} \mathrm{Sr} /{ }^{86} \mathrm{Sr}$ \\
\hline BCK112 & GN7/9a & upper C5b & 5.8 & -7.7 & - \\
\hline BCK99 & GN7/9a & upper $\mathrm{C} 5 \mathrm{~b}$ & 7.0 & -3.7 & 0.708374 \\
\hline BCK61 & GN7/9a & upper $\mathrm{C} 5 \mathrm{~b}$ & 6.0 & -4.0 & \\
\hline BCK44 & GN7/9a & upper C5b & 4.0 & -8.6 & 0.708118 \\
\hline BCK43 & GN7/9a & upper C5b & - & - & - \\
\hline BCK41 & GN7/9a & upper C5b & - & - & - \\
\hline BCK34 & GN7/9a & upper C5b & 5.6 & -4.4 & - \\
\hline BCK32 & GN7/9a & upper C5b & - & - & - \\
\hline BCK22 & GN7/9a & upper C5b & 2.8 & -2.8 & - \\
\hline BCK002 & GN7/9a & upper C5b & 1.1 & -2.8 & 0.708982 \\
\hline BCK290 & GX6c & $\mathrm{C} 5 \mathrm{~b}$ & 1.3 & -4.2 & - \\
\hline BCK252 & GX6c & $\mathrm{C} 5 \mathrm{~b}$ & 4.1 & -3.9 & - \\
\hline BCK206 & GX6c & $\mathrm{C} 5 \mathrm{~b}$ & 7.5 & -2.9 & - \\
\hline BCK201 & GX6c & $\mathrm{C} 5 \mathrm{a}$ & 1.5 & -3.2 & - \\
\hline
\end{tabular}

